\title{
Peercy to Give Plenary Speech on the Future of Semiconductor Materials Research
}

Paul S. Peercy, president of SEMI/ SEMATECH, a consortium of about 200 U.S.-owned and controlled semiconductor equipment and supplier companies, will present the plenary talk at the 1997 MRS Spring Meeting in San Francisco on Monday, March 31, 6:00 p.m., in Salon 7 at the San Francisco Marriott. In his discussion, "Semiconductor Materials Research for the Twenty-First Century," Peercy will elaborate on "projections for the future of the [semiconductor] industry, along with selected future materials and processing research needs."

Recent structural modifications in the semiconductor industry, driven by international competition and the increasing complexity of products and processes, is

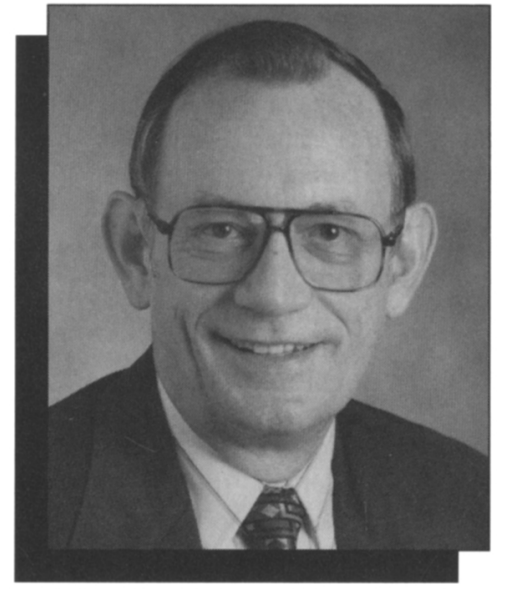

Paul S. Peercy

changing the way research and development is handled. Previously, large, vertically integrated companies not only manufactured integrated circuits but also conducted the research of materials, processes, and equipment for integrated circuits. Device manufacturers in the future will outsource materials and processing technology to supplier companies who will incorporate the technology into semiconductor manufacturing equipment.

Peercy received his $\mathrm{PhD}$ degree from the University of Wisconsin-Madison in 1966. He was meeting chair for the 1984 MRS Fall Meeting, served two terms as program chair for MRS, and served as councillor and as second vice-president of the Society.

\section{Bowman Receives OYI Award for Work on Polymers}

Christopher N. Bowman is the 1997 recipient of the Materials Research Society's Outstanding Young Investigator Award. The University of Colorado chemical engineering professor is cited "for seminal contributions to the field of highly crosslinked polymers, information storage materials, and computational methods in polymerization engineering."

The Outstanding Young Investigator Award recognizes exceptional, interdisciplinary scientific work in materials research by a young scientist or engineer who also displays leadership in the materials area.

Bowman's work focuses on kinetics and reaction engineering of multifunctional monomer polymerizations, preparation of novel membranes with specific active sites for separations, and preparation of microparticles with reactive sites for separations and purifications.

In his early studies, Bowman developed imaginative mathematical models to describe the polymerization reactions of multifunctional acrylates and methacrylates. He introduced the relaxation of the developing macromolecular structure to the kinetic model, and showed that certain phenomena such as volume shrinkage during polymerization can be explained by this relaxation process. Important applications of this work include the production of optical fibers, laser video disks, compact disks, and aspherical lenses. By developing wellcharacterized, crosslinked polymers, controlling the transport and release of solutes such as drugs, peptides, and proteins through such polymers should be possible.

Bowman has made major advances in understanding the kinetics of polymerization reactions. In a series of papers,

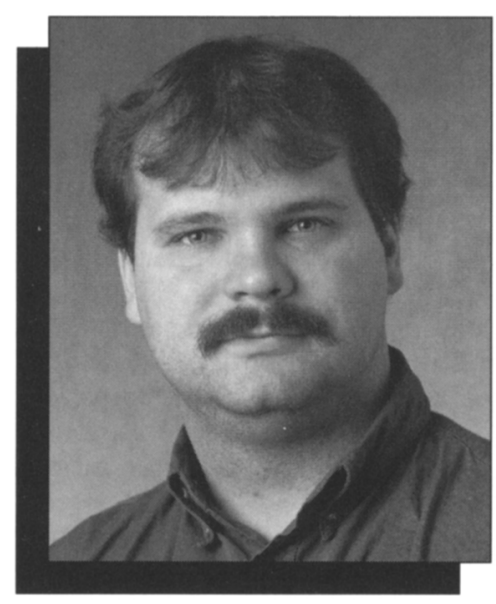

Christopher N. Bowman

Bowman demonstrated that a relaxational process, if coupled with the reactions, leads to chain diffusion dependent on free volume changes. He showed that the relaxation time can be calculated by real kinetic data, and he developed a calorimetric technique to follow the kinetics of fast ultraviolet-curing reactions. He also developed a laser interferometric technique to study the relaxational process. In a typical application, a liquid multifunctional monomer is exposed to light at room temperature and polymerized in seconds to form a densely-crosslinked polymer network.

An advanced kinetic gelation simulation developed by Bowman predicts the evolution of complex microstructures, particularly how the reaction conditions influence this evolution. In recent work, Bowman demonstrated that it is possible to simulate the gelation process in multi- methacrylate reactions in the presence of micro- and macrocyclization processes by considering diffusion-controlled phenomena. From this simulation, he developed a rational approach to design dental resins with improved properties. The maximum conversion of double bonds in existing dental resins can be increased by adding small amounts of a higher molecular weight monomer.

The increased conversion was achieved without compromising the mechanical strength and dimensional stability of the polymer restoration, and the shrinkage associated with polymerization decreased. Such studies provide pathways to resolve specific issues such as incomplete conversion of double bonds, mechanical strength, and ease of cure that are of such importance to the applicability of photocrosslinked polymers. His biomedical research addresses important aspects of the design, characterization, and evaluation of new dental materials.

Bowman received a $\mathrm{BS}$ and $\mathrm{PhD}$ degree in 1988 and 1991, respectively, in chemical engineering from Purdue University. He joined the faculty at the University of Colorado in 1992, and was promoted to associate professor three years later.

The OYI Award will be presented to Bowman on Monday, March 31, at 6:00 p.m. at the 1997 MRS Spring Meeting in San Francisco. He will also give a presentation, "Polymerizations and Properties of Polymer Stablized Ferroelectric Liquid Crystals," at 5:00 p.m. on Wednesday, April 2, in Symposium G at the Meeting His lecture will focus on understanding how polymers change electro-optic and phase behavior, and how liquid crystals influence the polymerization. 


\section{- Technical Symposia}

Twenty-six (26) technical symposia are offered during the 1997 Spring Meeting featuring the latest technological developments in materials science. The program has been designed to include intriguing new topics, all of which promote the interdisciplinary nature of materials science.

\section{- Symposium Tutorial Program}

Available only to meeting registrants, the tutorials will concentrate on new, rapidly breaking areas of research and are designed to encourage the exchange of information by meeting attendees during the symposium.

\section{- Exhibit}

A major exhibit encompassing the full spectrum of equipment, instrumentation, products, software, publications, and services will be held Tuesday through Thursday in Salon 8/9, San Francisco Marriott, adjacent to the technical meeting rooms. Meeting participants are invited to attend a reception on Tuesday evening from 5:00-6:30 p.m. in the exhibit area.

Complimentary coffee will be available during morning and afternoon breaks in the exhibit area, Tuesday through Thursday morning. Box lunches will be available Tuesday through Thursday during the noon break.

\section{- Poster Sessions}

Authors will be available Tuesday through Thursday for indepth discussions. Complimentary snacks and beverages will be available during these popular sessions.

\section{- Proceedings}

Many symposia from this meeting will publish proceedings. MRS members and meeting attendees may purchase copies of these proceedings at special prepublication prices and receive priority shipment upon publication. Prices will be higher following the meeting. To take advantage of these special prices, order your proceedings while registering for the meeting. For information on nonmember proceedings prices and ordering procedures, contact MRS Member Services.

\section{- Job Center}

A Job Center for MRS meeting attendees will be open Tuesday through Thursday, 8:00 a.m. - 5:00 p.m., in Sierra B/C, 5 th Floor, San Francisco Marriott. For additional information, check the MRS Website (http://www.mrs.org) or contact: Member Services, Materials Research Society, 9800 McKnight Road, Pittsburgh, PA 15237-6006; 412-3673004, ext. 402; Fax 412-367-4373; E-Mail: info @ mrs.org.

\section{- Networking Happy Hour}

TENTATIVE date: Tuesday, April 1, 7:00 - 8:00 p.m., location to be announced on site. Especially designed for students, postdocs, and other job seekers to meet informally with other MS\&E professionals to discuss employment issues. Snacks and beverages will be served.

\section{- Junior Faculty Forum: Grantsmanship}

TENTATIVE date: Monday, March 31, 12:00 noon - 1:00 p.m., location to be announced on site. Box lunches available.

\section{- Women in Materials Science and Education}

TENTATIVE date: Tuesday, April 1, 7:00 - 8:00 a.m., location to be announced on site. Continental breakfast available.

\section{STUDENT OPPORTUNITIES}

\section{- Symposium Aide Positions}

Graduate students who plan to attend the 1997 Spring Meeting and are willing to assist in the symposium presentations by operating audio-visual equipment are encouraged to apply for a Symposium Aide position. By assisting in a minimum of four half-day sessions, aides will earn a waiver of the student registration fee, a full-year MRS student membership commencing July 1, 1997, and a small stipend to help defray expenses. Symposium preferences are assigned on a first-come, first-serve basis. To request an application form and/or information, contact MRS Headquarters: (E-mail: info@mrs.org; Fax: 412-367-4373; Phone: 412-367-3003).

\section{- Student Mixer}

All graduate students and members of MRS University Chapters are invited to attend a reception in the San Francisco Marriott (date, time, and location to be announced in the on-site Meeting Guide). Student chapters are a vital part of MRS, providing discussion between students and faculty and promoting student interest in materials science. Don't miss this opportunity to meet with others involved in MRS student activities. Consult the MRS Website (http://www.mrs.org) for more information.

\section{- University Chapter Representatives}

Chapter officers and faculty advisors are invited to attend a meeting of MRS University Chapter representatives to compare notes on recent activities and brainstorm on new projects and issues of common concern. Anyone interested in starting a new chapter is also welcome (date, time, and location to be announced in the on-site Meeting Guide). For more information, contact June Maier, Member Services (maier@mrs.org).

\section{- Graduate Student Award Finalists' Special Talk Sessions}

Check the on-site Meeting Guide for the special talk session schedule.

\section{- Student Tip Sheet}

Consult the Student Tip Sheet on the MRS Website (http://www.mrs.org) for the latest information about student events at the meeting . 


\begin{tabular}{|c|c|c|c|c|c|c|c|c|}
\hline \multirow{2}{*}{\multicolumn{2}{|c|}{ SYMPOSIUM }} & \multirow[b]{2}{*}{ LOCATION } & \multicolumn{3}{|c|}{ MONDAY, MARCH 31} & \multicolumn{3}{|c|}{ TUESDAY, APRIL 1} \\
\hline & & & a.m. & p.m. & eve. ${ }^{\star}$ & a.m. & p.m. & eve. ${ }^{\star}$ \\
\hline A: & $\begin{array}{l}\text { Amorphous and Microcrys- } \\
\text { talline Silicon Technology }\end{array}$ & Golden Gate A2 & Tutorial Session & Tutorial Session & & $\begin{array}{l}\text { A1/G1: Amorphous Silicon Thin- } \\
\text { Film Transistors - 1 } \\
\text { A2/G2: Thin-Film Trans. - II }\end{array}$ & $\begin{array}{l}\text { A3: Carrier Kinetics \& Density } \\
\text { of States in a-Si }\end{array}$ & A4: Posters \\
\hline B: & $\begin{array}{l}\text { Epitaxial Growth - Principles } \\
\text { and Applications }\end{array}$ & Golden Gate C3 & $\begin{array}{l}\text { B1: Strained Layer Growth - } \\
\text { Morpholog.\& Compos. Evolution }\end{array}$ & $\begin{array}{l}\text { B2: Defect Formation, Strain } \\
\text { Relaxation, \& Growth Issues } \\
\end{array}$ & & $\begin{array}{l}\text { B3: Survey of Common Themes } \\
\text { in Epitaxial Growth - I }\end{array}$ & $\begin{array}{l}\text { B4: Survey of Common } \\
\text { Themes in Epitaxial Growth - II } \\
\end{array}$ & B5: Posters \\
\hline C: & $\begin{array}{l}\text { Processing of Compound } \\
\text { SCs for High-Speed Devices }\end{array}$ & Salon 13 & $\begin{array}{l}\text { C1: Materials and Character- } \\
\text { ization }\end{array}$ & C2: Materials and Processing & & C3: Processing and Devices & & \\
\hline D: & $\begin{array}{l}\text { Gallium Nitride and Related } \\
\text { Materials }\end{array}$ & Salon 7 & & & & $\begin{array}{l}\text { D1: Growth - Mechanisms and } \\
\text { Characterization }\end{array}$ & D2: Processing & D3: Posters \\
\hline E & $\begin{array}{l}\text { Defects and Diffusion in } \\
\text { Silicon Processing }\end{array}$ & Salon $1 / 2$ & & & & $\begin{array}{l}\text { E1: Defects and Diffusion } \\
\text { Phenomena in } \mathrm{Si} \text { - Impact on } \\
\text { Device Processing }\end{array}$ & $\begin{array}{l}\text { E2: Defect Properties and } \\
\text { Impurity-Defect Interactions } \\
\text { in } \mathrm{Si}\end{array}$ & \\
\hline F. & $\begin{array}{l}\text { Rapid Thermal and } \\
\text { Integrated Processing VI }\end{array}$ & Nob Hill B & & & & Tutorial Session & F1: Measurement & \\
\hline G: & $\begin{array}{l}\text { Flat Panel Display Materials } \\
\text { and Large-Area Processes }\end{array}$ & Golden Gate A1 & & Tutorial Session & & $\begin{array}{l}\text { G1/A1: Amorphous Silicon Thin- } \\
\text { Film Transistors - I } \\
\text { G2/A2: Thin-Film Transistors - II } \\
\text { (Golden Gate A2) }\end{array}$ & $\begin{array}{l}\text { G3: AMLCD Materials and } \\
\text { Processes } \\
\text { G4: Polysilicon AMLCDs }\end{array}$ & \\
\hline $\mathrm{H}$ : & $\begin{array}{l}\text { Organic Electronic Materials } \\
\text { and Devices } \\
\text { Sunday Tutorial Session }\end{array}$ & Golden Gate B1 & H1: Light-Emitting Devices & H2: Optical Devices & & H3: Field-Effect Transistors & H4: Light-Emitting Diodes & $\begin{array}{l}\text { H5: Materials } \\
\text { Preparation \& } \\
\text { Characteriz. }\end{array}$ \\
\hline l: & Polycrystalline Thin Films III & Golden Gate B2 & $\begin{array}{l}\text { 11: Evolution of Texture and } \\
\text { Microstructure - I }\end{array}$ & $\begin{array}{l}\text { 12: Evolution of Texture and } \\
\text { Microstructure - II }\end{array}$ & & $\begin{array}{l}\text { 13: Grain Boundaries and } \\
\text { Interfaces - I }\end{array}$ & $\begin{array}{l}\text { 14: Grain Boundaries and } \\
\text { Interfaces - 11 } \\
\text { 15: In-Room Posters }\end{array}$ & 16: Posters \\
\hline $\mathrm{J}:$ & $\begin{array}{l}\text { Materials Reliability in } \\
\text { Microelectronics VII }\end{array}$ & Salon $5 / 6$ & Tutorlal Session & J1: Adhesion and Fracture & & $\begin{array}{l}\text { J2: Future Interconnect/Copper } \\
\text { Reliability } \\
\text { J3: Gate-0xide Growth/Deposition }\end{array}$ & $\begin{array}{l}\text { J4/P3: Surface Preparation and } \\
\text { Gate-Oxide Reliability }\end{array}$ & \\
\hline K: & $\begin{array}{l}\text { Multilevel Process } \\
\text { Integration }\end{array}$ & Salon 3 & & & & K1: Barriers & K2: Interconnects - I & \\
\hline L: & Epitaxial 0xide Thin Films & Golden Gate C1 & L1: Epitaxial Ferroelectrics & L2: HTS Thin Films & & $\begin{array}{l}\text { L3: Colossal Magnetoresistive } \\
\text { Oxide Thin Films } \\
\end{array}$ & L4: CMR and Magnetic Oxides & $\begin{array}{l}\text { L5 }- \text { L10: } \\
\text { Posters }\end{array}$ \\
\hline M: & $\begin{array}{l}\text { Magnetic Ultrathin Films, } \\
\text { Multilayers, and Surfaces }\end{array}$ & Golden Gate C2 & $\begin{array}{l}\text { M1: Synthesis, Processing and } \\
\text { Characterization }\end{array}$ & $\begin{array}{l}\text { M2: Novel Applications and } \\
\text { Approaches for Magnetism }\end{array}$ & & $\begin{array}{l}\text { M3: Nano/Microstructure and } \\
\text { Magnetic Properties }\end{array}$ & $\begin{array}{l}\text { M4: Structure and Properties - } \\
\text { Mixing, Strain, and Steps }\end{array}$ & \\
\hline $\mathrm{N}:$ & $\begin{array}{l}\text { Low-Dielectric Constant } \\
\text { Materials \& Applications in } \\
\text { Microelectronics }\end{array}$ & Golden Gate B3 & & & & & Tutorial Session & \\
\hline 0 : & $\begin{array}{l}\text { Materials/Failure Analysis } \\
\text { for Silicon ULSI Processing }\end{array}$ & Salon 4 & & & & & Tutorial Session & \\
\hline & $\begin{array}{l}\text { Science \& Technology of SC } \\
\text { Surface Preparation }\end{array}$ & Golden Gate A3 & & & & $\begin{array}{l}\text { P1: Megasonic Cleaning } \\
\text { P2: R/D Coordination/SC1 } \\
\text { Technology }\end{array}$ & $\begin{array}{l}\text { P3/J4: Surface Preparation and } \\
\text { Gate-Oxide Reliability } \\
\text { (Salon 5/6) }\end{array}$ & \\
\hline Q: & $\begin{array}{l}\text { Thermoelectric Materials - } \\
\text { New Directions \& } \\
\text { Approaches }\end{array}$ & Salon 14 & & $\begin{array}{l}\text { Q1: Introduction to } \\
\text { Thermoelectric Materials }\end{array}$ & & $\begin{array}{l}\text { Q2: Artificial Structures - I } \\
\text { (Quantum Confinement, etc.) } \\
\text { Q3: New Materials - I }\end{array}$ & $\begin{array}{l}\text { Q4: Recent Advances in Bulk } \\
\mathrm{Bi}_{2} \mathrm{Te}_{3} \text { BiSb and PbTe Res. } \\
\text { Q5: Alternative Directions in } \\
\text { Thermoelectrics }\end{array}$ & Q6: Posters \\
\hline R: & $\begin{array}{l}\text { Matls. Issues Related to } \\
\text { Develop. of Textured High-T } \mathrm{c} \\
\text { Superconducting Conductors }\end{array}$ & Salon 15 & & & & $\begin{array}{l}\text { R1: Biaxially Textured YBCO } \\
\text { Conductors }\end{array}$ & $\begin{array}{l}\text { R2: Processing Issues for } \\
\text { Coated Conductors }\end{array}$ & R3: Posters \\
\hline S: & $\begin{array}{l}\text { Materials for Optical } \\
\text { Limiting II }\end{array}$ & Salon 11 & $\begin{array}{l}\text { S1: Organics - I } \\
\text { S2: Organics - II }\end{array}$ & $\begin{array}{l}\text { S3: Inorganics - I } \\
\text { S4: Inorganics - II } \\
\end{array}$ & & $\begin{array}{l}\text { S5: Photorefractives } \\
\text { S6: Liquid Crystals }\end{array}$ & $\begin{array}{l}\text { S7: Organics - III } \\
\text { S8: Organics - IV } \\
\end{array}$ & \\
\hline $\mathrm{T}:$ & $\begin{array}{l}\text { Computational Materials } \\
\text { Science at the Mesoscale }\end{array}$ & Nob Hill D & & & & $\begin{array}{l}\text { T1: Atomistic Approaches to } \\
\text { Dislocation Modeling }\end{array}$ & T2: Dislocation Dynamics & \\
\hline U: & $\begin{array}{l}\text { Rapid Prototyping and Solid } \\
\text { Freeform Manufacture }\end{array}$ & Salon 10 & $\begin{array}{l}\text { U1: Rapid Prototyping and Solid } \\
\text { Freeform Manufacturing -1 }\end{array}$ & $\begin{array}{l}\text { U2: Rapid Prototyping and Solid } \\
\text { Freeform Manufacturing - II }\end{array}$ & & $\begin{array}{l}\text { U3: Rapid Prototyping and Solid } \\
\text { Freetorm Manufacturing - III }\end{array}$ & & \\
\hline & $\begin{array}{l}\text { Interfacial Effects \& Organiz. } \\
\text { of Inorg.-Org. Comp. Solids }\end{array}$ & Nob Hill C & $\begin{array}{l}\text { V1: Ordered Micro- and } \\
\text { Mesoporous Inorganic Oxides }\end{array}$ & $\begin{array}{l}\text { V2: Mesostructured Inorganic- } \\
\text { Surfactant Materials }\end{array}$ & & V3: Inorganic-Organic Thin Films & $\begin{array}{l}\text { V4: Heterogeneous Inorganic- } \\
\text { Polymer Composites }\end{array}$ & V5: Posters \\
\hline W: & $\begin{array}{l}\text { Metast. \& Critical Phenom. } \\
\text { in Polymer Phase Behavior }\end{array}$ & Salon 12 & W1: Crystalline Polymers - I & W2: Crystalline Polymers - II & & $\begin{array}{l}\text { W3: Block Copolymers and } \\
\text { Polymer Blends - I }\end{array}$ & $\begin{array}{l}\text { W4: Block Copolymers and } \\
\text { Polymer Blends - II }\end{array}$ & \\
\hline & $\begin{array}{l}\text { Frontiers of Materials } \\
\text { Research }\end{array}$ & Salon 7 & & $\mathrm{x} 1$ & & & $\mathrm{X}_{2}$ & \\
\hline & $\begin{array}{l}\text { Materials in Sports and } \\
\text { Recreation }\end{array}$ & Nob Hill A & & & & & $\begin{array}{l}\text { Y1: Materials in Sailing and } \\
\text { Wind Surfing }\end{array}$ & \\
\hline$z$ & $\begin{array}{l}\text { Workshop on Specimen } \\
\text { Prep. for TEM of Materials IV }\end{array}$ & Salon 13 & & & & & & \\
\hline
\end{tabular}

MRS 1997 Spring Meeting Tutorial Program

\begin{tabular}{|c|c|c|}
\hline Sunday • March 30 & Monday • March 31 & Tuesday • April 1 \\
\hline \multirow[t]{3}{*}{$\begin{array}{c}\text { Symposium H } \\
\text { 1:00-5:00 p.m. } \\
\text { STH: Organic Electronic Materials } \\
\text { and Devices } \\
\text { Room: Golden Gate B1 }\end{array}$} & $\begin{array}{c}\text { Symposium A } \\
\text { 8:30 a.m. - 4:30 p.m. } \\
\text { STA: Amorphous Silicon Materials and } \\
\text { Devices for Large-Area Electronics } \\
\text { Room: Golden Gate A2 }\end{array}$ & $\begin{array}{c}\text { Symposium F } \\
\text { 8:00 a.m. - 12:00 noon } \\
\text { STF: Rapid Thermal and Integrated } \\
\text { Processing } \\
\text { Room: Nob Hill B }\end{array}$ \\
\hline & $\begin{array}{c}\text { Symposium G } \\
\text { 1:30-5:00 p.m. } \\
\text { STG: Flat Panel Display Materials and } \\
\text { Large-Area Processing } \\
\text { Room: Golden Gate A1 }\end{array}$ & $\begin{array}{c}\text { Symposium N } \\
\text { 1:00 - 5:00 p.m. } \\
\text { STN: Low-Dielectric-Constant Materials for } \\
\text { B.E.O.L. High-Performance Integrated } \\
\text { Circuits } \\
\text { Room: Golden Gate B3 }\end{array}$ \\
\hline & $\begin{array}{l}\text { Symposium J } \\
\text { 8:30 a.m. - 12:00 noon } \\
\text { STJ: The Role of Mechanical Properties and } \\
\text { Microstructure in the Reliability of Advanced } \\
\text { Microelectronic Interconnect Systems } \\
\text { Room: Salon } 5 / 6\end{array}$ & $\begin{array}{c}\text { Symposium O } \\
\text { 1:00 - 6:00 p.m. } \\
\text { STO: Diagnosis of ULSI Circuits } \\
\text { Room: Salon } 4\end{array}$ \\
\hline
\end{tabular}




\begin{tabular}{|c|c|c|c|c|c|c|c|}
\hline \multicolumn{3}{|c|}{ "WEDNESDAY, APRIL 2} & \multicolumn{3}{|c|}{ THURSDAY, APRIL 3} & \multicolumn{2}{|c|}{ FRIDAY, APRIL 4} \\
\hline a.m. & p.m. & eve.* & a.m. & p.m. & eve. ${ }^{\star}$ & a.m. & p.m. \\
\hline A5: Microcrystalline Silicon & $\begin{array}{l}\text { A6: Growth } \\
\text { A7: Hydrogen }\end{array}$ & & $\begin{array}{l}\text { A8: 20th Anniversary of the } \\
\text { Staebler-Wronski Effect }\end{array}$ & $\begin{array}{l}\text { A9: Solar Cells } \\
\text { A10: Alloys }\end{array}$ & A11: Posters & $\begin{array}{l}\text { A12: Devices } \\
\text { A13: Hot-Wire Deposition }\end{array}$ & \\
\hline $\begin{array}{l}\text { B6: Epitaxial Growth Kinetics - Si } \\
\text { and SiGe Alloys }\end{array}$ & $\begin{array}{l}\text { B7: Epitaxy of Metastable Alloys } \\
\text { and Other Compounds }\end{array}$ & & & & & & \\
\hline \multicolumn{8}{|l|}{ C } \\
\hline D4: Doping/Contacts & D5: Devices & & $\begin{array}{l}\text { D6: Quantum Structures and } \\
\text { Theory }\end{array}$ & D7: Characterization & D8: Posters & D9: Growth Substrates & \\
\hline $\begin{array}{l}\text { E3: Transient-Enhanced Diffusion } \\
\text { E4: Low-Energy Implants and } \\
\text { Shallow Junctions }\end{array}$ & $\begin{array}{l}\text { E5: Defect Evolution in lon- } \\
\text { Implanted Si } \\
\text { E6: Modeling of TED and Defect } \\
\text { Evolution - I } \\
\end{array}$ & E7: Posters & $\begin{array}{l}\text { E8: Diffusion Mechanisms in } \mathrm{Si} \\
\text { E9: Gettering Procedures and } \\
\text { Mechanisms }\end{array}$ & $\begin{array}{l}\text { E10: Interaction Between Point } \\
\text { and Extended Defects } \\
\text { E11: Effect of Pressure and } \\
\text { Strain on Defect Properties }\end{array}$ & $\begin{array}{l}\text { E12, E13: } \\
\text { Posters }\end{array}$ & $\begin{array}{l}\text { E14: Defect Migration and } \\
\text { Agglomeration at Low Temperature } \\
\text { E15: Modeling of TED and Defect } \\
\text { Evolution- } 11\end{array}$ & \\
\hline $\begin{array}{l}\text { F2: RTCVD } \\
\text { F3: Modeling and Manufacturing } \\
\text { Issues }\end{array}$ & $\begin{array}{l}\text { F3: Modeling and Manufacturing } \\
\text { Issues (cont'd) }\end{array}$ & & $\begin{array}{l}\text { F4: Integrated Processing } \\
\text { F5: Silicides }\end{array}$ & $\begin{array}{l}\text { F6: Annealing and Defects } \\
\text { F7: Dielectrics - } 1\end{array}$ & & $\begin{array}{l}\text { F8: Dielectrics - II } \\
\text { F9: RTP of III-V Materials and } \\
\text { Other Novel Applications } \\
\end{array}$ & \\
\hline $\begin{array}{l}\text { G5: Novel Materials and Systems } \\
\text { G6: Liquid Crystal and Filter } \\
\text { Materials }\end{array}$ & $\begin{array}{l}\text { G7: FEDs - I } \\
\text { G8: FEDs - II } \\
\text { 5:00 PM Outstanding Young } \\
\text { Investigator Oral Presentation }\end{array}$ & $\begin{array}{l}\text { G9, G10, G11: } \\
\text { Posters }\end{array}$ & $\begin{array}{l}\text { G12: Phosphor Materials } \\
\text { G13: Nanocrystals and EL }\end{array}$ & $\begin{array}{l}\text { G14: Novel Approaches to } \\
\text { Phosphors } \\
\text { G15: Phosphor Materials and } \\
\text { Processing }\end{array}$ & & & \\
\hline $\begin{array}{l}\text { H6: Device Reliability and } \\
\text { Degradation }\end{array}$ & H7: Optical/Transport Properties & H8: Posters & & & & & \\
\hline $\begin{array}{l}\text { 17: Characterization and } \\
\text { Representation }\end{array}$ & $\begin{array}{l}\text { 18/J7: Microstructure, Texture and } \\
\text { Reliability }\end{array}$ & 19: Posters & $\begin{array}{l}\text { 110: Polycrystalline Si and SiGe } \\
\text { Films - I }\end{array}$ & $\begin{array}{l}\text { 111: Polycrystalline Si and SiGe } \\
\text { Films - II }\end{array}$ & & & \\
\hline $\begin{array}{l}\text { J5: Gate Stack and 0xide } \\
\text { Interfaces } \\
\text { J6: Oxide Degradation and Defects }\end{array}$ & $\begin{array}{l}\text { J7/18: Microstructure, Texture and } \\
\text { Reliability } \\
\text { (Golden Gate B2) } \\
\end{array}$ & J8: Posters & $\begin{array}{l}\text { J9: Novel Measurement Techniques } \\
\text { J10: Electromigration Modeling }\end{array}$ & $\begin{array}{l}\text { J11: Electromigration and } \\
\text { Microstructure } \\
\text { J12: Stress \& Stress Relaxation }\end{array}$ & & & \\
\hline $\begin{array}{l}\text { K3: Silicides } \\
\text { K4: Interconnects - II }\end{array}$ & $\begin{array}{l}\text { K5: Interconnects - III } \\
\text { K6: In-Room Posters } \\
\end{array}$ & & & & & & \\
\hline L11: Substrates for Oxide Epitaxy & L12: Oxide Structure and Growth & & & & & & \\
\hline $\begin{array}{l}\text { M5: Nanoscale Magnetic } \\
\text { Confinement, Particles, and Arrays }\end{array}$ & $\begin{array}{l}\text { M6: Magnetization Reversal and } \\
\text { Domain Structure }\end{array}$ & M7: Posters & $\begin{array}{l}\text { M8: Synchrotron Radiation Studies } \\
\text { of Magnetic Materials }\end{array}$ & $\begin{array}{l}\text { M9: Magneto-Optical Properties, } \\
\text { Effects and Measurements }\end{array}$ & M10: Posters & $\begin{array}{l}\text { M11: Spin-Dependent Transport - } \\
\text { CMR and Tunneling }\end{array}$ & $\begin{array}{l}\text { M12: Inter- } \\
\text { layer Coupling } \\
\text { \& Spin Polariz }\end{array}$ \\
\hline $\begin{array}{l}\text { N1: Organic and Inorganic } \\
\text { Dielectrics }\end{array}$ & $\begin{array}{l}\text { N2: Interfaces and Porous } \\
\text { Materials }\end{array}$ & & $\begin{array}{l}\text { N3: Measurement and } \\
\text { Characterization }\end{array}$ & N4: Vapor-Deposited Materials & & $\begin{array}{l}\text { N5: Fluorinated Oxides and } \\
\text { Polyimides }\end{array}$ & \\
\hline 01: Microcontamination & 02: Metrology and Defectivity & 03: Posters & $\begin{array}{l}\text { 04: Materials and Process } \\
\text { Characterization }\end{array}$ & 05: Failure Analysis & & 06: Emerging Analytical Methods & \\
\hline $\begin{array}{l}\text { P4: CMP/CMP Cleaning } \\
\text { P5: Post-Etch Processing }\end{array}$ & $\begin{array}{l}\text { P6: Surface Microroughness } \\
\text { P7: Wet Chemical Cleaning and } \\
\text { Gate-Oxide Integrity }\end{array}$ & P8: Posters & $\begin{array}{l}\text { P9: Analytical Studies of Surfaces } \\
\text { P10: Wet Chemical Cleaning/Etch. }\end{array}$ & $\begin{array}{l}\text { P11: Dry Water Cleaning } \\
\text { P12: Environmentally Friendly } \\
\text { Processing }\end{array}$ & & & \\
\hline $\begin{array}{l}\text { Q7: Artificial Structures - II } \\
\text { (Quantum Confinement, etc.) } \\
\text { Q8: Skutterudites }\end{array}$ & $\begin{array}{l}\text { Q9: New Materials - II } \\
\text { 010: Silicides }\end{array}$ & & $\begin{array}{l}\text { Q11: Industry \& Application Interest } \\
\text { in New Thermoelectric Materials } \\
\text { Q12: Govt. \& Military Interest in } \\
\text { New Thermoelectric Materials }\end{array}$ & $\begin{array}{l}\text { Q13: New Materials - III } \\
\text { Q14: Thermoelectrics Panel } \\
\text { Discussion - New Directions and } \\
\text { Approaches }\end{array}$ & & & \\
\hline $\begin{array}{l}\text { R4: Critical Currents, Pinning, and } \\
\text { Grain Boundaries }\end{array}$ & $\begin{array}{l}\text { R5: Processing of Deposits, } \\
\text { BSCCO, and New Materials }\end{array}$ & R6: Posters & & & & & \\
\hline $\begin{array}{l}\text { S9: Characterization } \\
\text { S10: Devices \& Beam Propagation }\end{array}$ & & S11: Posters & & & & & \\
\hline T3: Microstructural Evolution & T4: Process Modeling & T5: Posters & $\begin{array}{l}\text { T6: Mechanical Behavior and } \\
\text { Materials Properties }\end{array}$ & $\begin{array}{l}\text { T7: Linking Computational Length } \\
\text { and Time Scales }\end{array}$ & & $\begin{array}{l}\text { T8: Atomistic Simulation Methods } \\
\text { and Results }\end{array}$ & \\
\hline \multicolumn{8}{|c|}{ 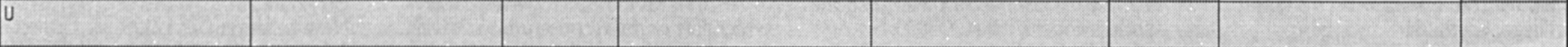 } \\
\hline $\begin{array}{l}\text { V6: Structure-Directed } \\
\text { Condensation Processes }\end{array}$ & $\begin{array}{l}\text { V7: Inorg-Organic Interac. in Sol- } \\
\text { Gel, Silicon Carb., \& Polymeric Sys. }\end{array}$ & & & & & & \\
\hline $\begin{array}{l}\text { W5: Liquid Crystalline Polymer } \\
\text { Systems - I }\end{array}$ & $\begin{array}{l}\text { W6: Liquid Crystalline Polymer } \\
\text { Systems - II }\end{array}$ & & $\begin{array}{l}\text { W7: Metast. Polymer Structuref } \\
\text { Patterns I }\end{array}$ & $\begin{array}{l}\text { W8: Metast. Polymer Structure/ } \\
\text { Patterns II }\end{array}$ & & & \\
\hline$x$ & $x_{3}$ & & & $\mathrm{x} 4$ & & & \\
\hline $\begin{array}{l}\text { Y2: Developments in Cars and } \\
\text { Bicycles }\end{array}$ & $\begin{array}{l}\text { Y3: Skiing, Baseball and Other } \\
\text { Activities - Innov. Mats. \& Designs }\end{array}$ & & & & & & \\
\hline 2 & 21 & 22: Posters & & & & & \\
\hline
\end{tabular}

\section{LOCATION/LODGING/TRAVEL}

San Francisco Marriott Hotel 55 Fourth Street

San Francisco, CA 94103

(800) 228-9290 Nationwide

(415) 896-1600 Main Desk

(415) 442-6755 Reservations

Reservation Fax (415) 442-0141

\section{Deadline for Hotel Reservations: March 1, 1997}

A block of rooms has been reserved for MRS meeting attendees at the San Francisco Marriott Hotel ( 30 minutes from the San Francisco International Airport). When making your reservations, mention the Materials Research Society to receive the special rate.

\section{Airline Transportation}

The official travel management company for the Materials Research Society's 1997 Spring Meeting is Giselle's Travel Bureau. They will guarantee the lowest fares on any airline at time of booking. Call Giselle's, 800-523-0100, Monday through Friday, 7:30 a.m. - 5:30 p.m. PST; or Fax 916-565-0936, and mention the Materials Research Society's meeting.

MRS meeting attendees receive the following travel benefits and services: - Lowest fares on any airline guaranteed - Computerized driving instructions from major U.S. airports upon request • Car rental savings

\section{Local Transportation}

The San Francisco Airporter service is available between the airport and downtown San Francisco hotels. 
The MRS Exhibit, held in conjunction with the 1997 MRS Spring Meeting, will encompass the full spectrum of equipment, instrumentation, products, software, publications and services for materials research. As always, the exhibit will closely parallel the nature of the technical symposia. The technical program has been arranged to allow meeting participants ample opportunity to visit the exhibit, and MRS encourages attendees to visit the exhibit by scheduling coffee breaks, deli-style lunches, and a meeting-wide reception in exhibit hall.

\title{
Exhibit Hours:
}

\author{
Tuesday, April 1 \\ Wednesday, April 2 \\ 11:30 a.m. - 6:30 p.m. \\ Thursday, April 3
Complimentary Reception from 5:00 p.m. - 6:30 p.m.
9:00 a.m. - 5:00 p.m.
9:00 a.m. - 1:30 p.m.

Partial List of 1997 Spring Exhibitors (as of January 10, 1997) denotes MRS Corporate Affiliate

\begin{abstract}
A \& N Corporation
377 Highway $40 \mathrm{~W}$.

P.O. Box 878

Inglis, FL 34449

Telephone: 352-447-2411; 800-352-6431

Fax: 352-447-2322

A\&N Corporation has been a manu-

facturer of high vacuum components

since 1965 . Our product lines include:

ISO-KF (QF) flanges, ISO-MF (LF)

flanges, UHV (CF) flanges, ASA

flanges, Vacuum couplings,

Feedthroughs, and Vacuum Ball

Valves. We maintain extensive inven-

tories of all catalogued items, and rou-

tinely ship products on a same or next

day basis.
\end{abstract}

\section{$\triangle \mathrm{ABB}$ Extrel}

575 Epsilon Drive

Pittsburgh, PA 15238-2838

Telephone: 412-967-5752

Fax: 412-963-6578

E-mail: davek@extrel.com

ABB Extrel has been manufacturing

Quadrupole Mass Spectrometers and System since 1964. Our instruments ${ }^{\prime}$ high sensitivity and resolution allow us to monitor and control processes that simple residual gas analysis

(RGA) cannot detect. We place special emphasis on plasma and CVD, molecular beam, environmental abatement and high-purity gas applications.

Academic Press, Inc.

525 B Street, Suite 1900

San Diego, CA 92101

Telephone: 619-699-6774

Fax: 619-699-6580

http:/ / apnet.com

With $50+$ year of experience, Academic Press continues its quest for excellence in scientific, technical publishing. Our three offices, San Diego, California;

Cambridge, Massachusetts; and

London, England, collectively publish

400 new book titles and 212 journals each year.

\section{Accurel Systems International \\ Corporation \\ 785 Lucerne Drive \\ Sunnyvale, CA 94086 \\ Telephone: 408-737-3892 DC Power Supplies, ATC Sputtering Systems, Microwave Power Supplies and Components, ECR Sources, Diamond Film Equipment, and Electrostatic Chucks.}

Fax: 408-737-3916

E-mail: accurel@ix.netcom.com

http://www.semiweb.com/accurel

With a long, successful history providing high-quality, advanced technology services to users and manufacturers of semiconductor devices, Accurel Systems can aid in your technological challenges and reduce your time to market through: FIB Technology, Turnkey Failure Analysis,

Deprocessing, FE-SEM, TEM, E-Beam Probing, Emission Microscopy,

Decapping, and Quick-turn Assembly.
Aetrium, Inc.

Telephone: $612-770-2000$

Fax: 612-770-7975

Aetrium designs and manufactures a variety of electro-mechanical equipment used for quality verification in semiconductor manufacturing. This includes Reliability Systems for Electromigration, Hot Carrier and TDDB testing applications, and Thermal Conditioning and Control products which use conductive heating/cooling for test temperatures from $-60^{\circ} \mathrm{C}$ to $250^{\circ} \mathrm{C}$ with DUT loads of up to 100 watts. (1) Semiconductor reliability test stations: Model ST-4 electromigration, Model 1164 TDDB, MOS, bipolar device testing. (2) Environmental test, burn-in, life test systems and thermal conditioning and control products: QubePak ${ }^{\mathrm{TM}}$ and BakPak ${ }^{\mathrm{TM}}$.

$\checkmark$ AIXTRON, Inc.

1569 Barclay Blvd.

Buffalo Grove, IL 60089

Telephone: 847-215-7335

Fax: 847-215-7341

AIXTRON, the leading manufacturer of MOCVD and VPE equipment for the growth of all III- $V$, including nitrides, II-VI, oxides and SiC.

Outstanding quality in manufacturing, reliability in safety, and highest uniformity results for epilayers. Systems AIX-200, AIX200/4, AIX-2400, and the world's largest, the AIX-3000.

AJA International, Inc.

P.O. Box 246

809 Country Way

N. Scituate, MA 02060

Telephone: $617-545-7176$

Fax: 617-545-4105

Magnetron Sputtering Sources (circular, rectangular, cylindrical and "tilting head" versions), Sputtering "Cluster Flanges, " Heated/Cooled Substrate Holders, Sputtering Targets, RF and

American Institute of Physics, Inc. 500 Sunnyside Blvd.

Woodbury, NY 11797

Telephone: 516-576-2484

Fax: 516-576-2374

E-mail: corr@aip.org

http:/ / www.aip.org

The American Institute of Physics represents the interests of scientist through service to its Member

Societies. AIP also publishes a wide range of physics information in the ference proceedings. Stop by our
2350 Helen Street

North St. Paul, MN 55109 form of journals, magazines, and con- booth for a demonstration of the recently launched Online Journal Service which will allow our journal subscribers to access important physics information at their desktops Don't forget to apply for your FREE subscription to The Industrial Physicist.

-APD Cryogenics, Inc.

1833 Vultee Street

Allentown, PA 18103

Telephone: 610-791-6700

Fax: 610-791-0561

E-mail: sales@apdcryogenics.com http:/ / www.apdcryogenics.com APD's Displex product line, the industry-standard for 2-stage GM expanders, allows the user the versatility of a broad temperature range (6.5-450 Kelvin) coupled with an enormous variety of specialized attachments for customization to your application. Also from APD Heli-tran ${ }^{\circledR}$ open-cycle systems, Heliplex ${ }^{\circledR}$ for experimentation to 4.2 Kelvin, the Omniplex ${ }^{B}$ exchange gas cryostat, and CRYOTIGER@; a closedcycle system for use instead of $\mathrm{LN}_{2}$.

\section{ASTeX/Applied Science and} Technology. Inc.

35 Cabot Road

Woburn, MA 01801

Telephone: 617-933-5560

Fax: 617-933-0750

E-mail: sales@astex.com

ASTeX provides microwave power generators, high concentration ozone generators and systems, a range of ECR plasma sources for etching and deposition, downstream microwave plasma sources for ashing, etching and oxidation of thin films, and turnkey diamond CVD systems.

- Bede Scientific Incorporated

14 Inverness Drive East, Suite G-104

Englewood, CO 80112

Telephone: $303-790-8647$

Fax: 303-790-8648

E-mail: info@bede.com

Bede Scientific is a world leader in materials characterization, established for many years in High Resolution X-ray Diffraction and Scattering techniques, largely in the semiconductor industry. Bede developed the world's first quality control diffractometer. while recent advances include combined XRD and photoluminescence mapping and the first commercial Brillouin Spectrometer.
- Blake Industries, Inc. 660 Jerusalem Road Scotch Plains, NJ 07076

Telephone: 908-233-7240

Fax: 908-233-1354

E-mail: BLAKEINDUSTRIESINC@ worldnet.att.net

Blake Industries will be exhibiting

Huber rotary tables, translation stages, goniometer heads, $X-Y$ slits for synchrotron and rotating anode experiments. Blake monochromators, thinfilm cameras, and Laue equipment will also be displayed.

Burleigh Instruments, Inc Burleigh Park

Fishers, NY 14453-0755

Telephone: 716-924-9355

Fax: 716-924-9072

E-mail: info@burleigh.com http://www.burleigh.com

Burleigh will exhibit our line of Scanning Probe Microscopes. This new generation of microscopes includes AFM, STM and UHV/STM. They are all extremely affordable, highperformance microscopes designed for routine imaging of fine surface topography with precise 3-D quantification Burleigh also manufactures instruments for submicron linear positioning and laser characterization.

\section{Ceramaseal}

P.O. Box 260

US Route 20

New Lebanon, NY 12125

Telephone: 518-794-7800

Fax: 518-794-8080

http: / / www.ceramaseal.com Ceramaseal offers a full range of standard ultra-high vacuum feedthroughs, connectors, thermocouples, cables, viewports and related hardware. New products include Crystal Quartz viewports pressure rated to $500 \mathrm{psi}$ and high temperature micro " $D$ " series connectors 9 pin through 50 pin.

\section{CHA Industries}

4201 Business Center Drive

Fremont, CA 94538-6357

Telephone: 510-683-8554

Fax: 510-683-0910

CHA Industries provides multipurpose and custom vacuum deposition systems utilizing electron beam, sputtering, thermal, ion beam and roll coater techniques. Systems can be configured for a variety of today's requirements incorporating user-friendly computer control and innovative ergonomics. A wide range of vacuumrelated components is available from CHA Industries. 
- Chemat Technology, Inc

19365 Business Center Drive, \#8\&99

Northridge, CA 91324

Telephone: 818-727-9786

Fax: 818-727-9477

E-mail: aol@chemat.com

Chemat Technology specializes in solgel and MOCVD technologies. We supply a full line of products used in sol-gel and MOCVD processes, from precursors (metal alkoxides) to equipment (dip-coater and spin-coater). Our technical staff will work with you to find appropriate precursors and processes for your applications. Chemat also offers sol-gel R\&D effort and custom coating. Other products include unique ultrahigh surface area powder (up to $500 \mathrm{~m}^{2} / \mathrm{g}$ )

\section{- Commonwealth Scientific}

Corporation

500 Pendleton Street

Alexandria, VA 22314

Telephone: 703-548-0800

Fax: 703-548-7405

E-mail: csc@ionbeam.com

Commonwealth Scientific Corporation (CSC) is the leader in ion beam technology, manufacturing a complete line of ion beam sources and systems for surface modification processes including nitriding, dry etching and thin film deposition. CSC will be displaying their complete line of $\mathrm{DC}$ and $\mathrm{RF}$ ion sources ranging from $3 \mathrm{~cm}$ to $38 \mathrm{~cm}$ in diameter.

Creekside Technologies Corporation 2405 Annapolis Lane, C220

Plymouth, MN 55441

Telephone: 612-559-4655

Fax: 612-559-4244

E-mail: crksd@aol.com

Creekside Technologies Corporation is the key provider of spare parts, service support and upgrades for

Varian/Intevac Auger electron spectrometers (AES), low and reflection high energy electron diffraction components (LEED and RHEED) and ion guns. In addition, Creekside Technologies offers new designs and consulting services for electron and ion optics.

Cryomech Inc.

113 Falso Drive

Syracuse, NY 13211

Telephone: 315-455-2555

Fax: 315-455-2544

E-mail: specs@cryomech.com

http://www.cryomech.com

Cryomech Inc. manufactures Gifford-

McMahon Cycle Cryorefrigerators,

Cryostats and Liquid Nitrogen Plants. From the standard laboratory cryostat to the customized cryostat for the unique experiment, Cryomech has the experience and the cryogenic equipment to meet your requirements in all capacity/temperature ranges. Systems available down to $2.2 \mathrm{~K}$

DCA Instruments, Inc.

400 West Cummings Park, Suite 3900

Woburn, MA 0180

Telephone: 617-937-6550

Fax: 617-935-2405

E-mail: rebecca@dca.fi

DCA Instruments specializes in the design and manufacture of high-quality UHV deposition systems, offering standard systems for the following deposition techniques: III-V, II-VI, CMT-MBE, metal MBE, UHV sputtering, UHV laser ablation, and UHV CVD. DCA Instruments also offers a wide range of $\mathrm{MBE}$ components which are retrofittable to the majority of existing systems. Components include effusion cells, soft-action magnetically driven linear shutters, a 'zero-wobble' substrate manipulator and a self-regulating Mercury source.

\section{- Denton Vacuum, Inc.}

1259 North Church Street

Moorestown, NJ 08057

Telephone: $609-439-9100$

Fax: 609-439-9111

E-mail: j_campbell@dentonvacuum.com http: / / www.dentonvacuum.com

Denton Vacuum is a premier manufacturer of High Vacuum Thin Film Deposition Systems. For applications ranging from the preparation of samples for electron microscopy, semiconductor failure analysis and quality control, thin film research, and production-size optical coating systems; Denton Vacuum offers an appropriate system to meet a wide range of technical requirements. In addition to its system offerings, DVI also has a wide variety of accessory equipment such as Electron Beam Evaporation Guns and Power Supplies, Ion Sources, Optical Monitors, Sputter Cathodes,

Feedthroughs, and Thermal

Evaporation Supplies.

(see ad in this issue)

\section{Digital Instruments, Inc}

520 E. Montecito Street

Santa Barbara, CA 93103

Telephone: 805-899-3380

Fax: 805-899-3392

E-mail: Terry@di.com

http://www.di.com

Digital Instruments, the world leader in Scanning Probe Microscopy (SPM) will be exhibiting its NanoScope ${ }^{\circledR}$ SPMS including the MultiMode ${ }^{\mathrm{TM}}$ Atomic Force Microscope (AFM), the world's best selling and highest resolution SPM. Featured this year is the Dimension $^{\mathrm{TM}} 3000$ SPM/AFM offering the complete range of SPM techniques for small or large samples including topography, magnetic force, lateral force, electrochemistry, TappingMode ${ }^{\mathrm{TM}}$, force modulation and others. We'1l also be demonstrating our new Phase Imaging Technique, a fast and easy method of differentiating regions of differing composition, friction, adhesion, viscoelasticity, etc on sample surfaces. (see ad in this issue)

Duniway Stockroom Corp.

1305 Space Park Way

Mountain View, CA 94043-1308

Telephone: 800-446-8811

Fax: 415-965-0764

E-mail: info@duniway.com

http: / / www.duniway.com

New replacement parts for ion pumps leak detectors, and vacuum systems; including 12-point bolts, copper gaskets, TC gauges, ion gauges, oil for diffusion pumps, etc. Surplus vacuum equipment for sale, rebuilt to original performance. 48-page catalog, including prices, shows new and surplus equipment

Eagle-Picher Industries, Inc.

Electro-Optic Materials (EOM) Dept

P.O. Box 737

Highway $69 \mathrm{~A}$

Quapaw, OK 74363

Telephone: 918-673-1650

Fax: 918-673-2121

The "EOM" Department of Eagle-

Picher Industries, Inc. is a manufactur- er of Ultra High Purity Gallium Metal,

Gallium Trichloride, Gallium

Sesquioxide, Germanium

Tetrachloride, Germanium Dioxide,

Intrinsic Germanium Metal

Germanium Substrates, Germanium, and Silicon Infrared Optical Materials. Eagle-Picher also purchases scrap Gallium and Germanium, in many forms, for RECYCLING.

\section{EDAX International}

\section{McKee Drive}

Mahwah, NJ 07430

Telephone: 201-529-4880

Fax: 201-529-3156

EDAX INTERNATIONAL-A leading innovator in the design and manufacture of Energy Dispersive X-Ray Microanalysis Systems and X-Ray Fluorescence products. On an international basis, this ISO 9001 Certified company supplies PC and MAC-based elemental analysis systems, analysis software, digital imaging, non-destructive XRF products and a complete line of Be, UTW and SUTW detectors: including cryo- $x$ and R-TEM, the retractable TEM detector.

\section{Elsevier Science}

655 Avenue of the America

New York, NY 10010-5107

Telephone: 212-633-3766

Fax: 212-633-3990

E-mail: usinfo-f@elsevier.com

http:/ / www.elsevier.com

Stop by the Elsevier booth for a

demonstration of Solid State

Communications Online, the new electronic journal. Also on display will be a wide range of books and journals in the field of Materials Science ranging from fundamental solid state physics to materials processing. Renowned journal titles include Acta Materialia Solid State Communications, Polymer, Materials Research Bulletin, and Progress in Surface Science. Elsevier Advanced Technology will be pleased to supply sample copies of the leading magazine dedicated to the Compound Semiconductor community. Each issue of III-Vs Review covers the latest research from around the world-materials, processing, devices, production techniques-plus new product launches and industry news. Free sample copies of all Elsevier journals and magazines are available at the booth. In addition, a $20 \%$ discount is available on all books on display including Encyclopedia of Advanced Materials and Handbook of Crystal Growth Don't forget to sign up at the booth for our FREE information services including Contents Direct and Contents Alert.

\section{- EMCORE Corporation}

394 Elizabeth Avenue

Somerset, NI 08873

Telephone: 908-271-9090

Fax: 908-271-9686

E-mail:peter@emcore.com

http://www.emcore.com

EMCORE Corporation manufacture Turbodisc Deposition systems for the MOCVD of semiconductor, advanced oxide and other electronic material thin films. TurboDisc technology produces films with the interface abruptness and uniformity of thickness, composition, and doping required by the most advanced devices. EMCORE systems are further distinguished by low cost of ownership, high throughput, excellent reproductibility, low maintenance needs, and high reliability.

EPI/MBE Products Group

1290 Hammond Road

St. Paul, MN 55110

Telephone: $612-653-0488$

Fax: 612-653-0725

E-mail: info@epimbe.com

http: / / www.epimbe.com

$\mathrm{EPI}$ is the largest MBE equipment manufacturer in North America and has been the international leader in quality and innovation in the MBE field since 1986. Our 2500 EPI Effusion cells are currently in use in over 360 facilities worldwide. Our MBE systems are available for use with GaAs/A1GaAs, Antimonides, Phosphides, Silicon and II-VI materials.

Epion/PVD Products

4R Alfred Circle

Bedford, MA 01730

Telephone: 617-275-3703

Fax: 617-275-3709

E-mail: jgreerPVD@aol.com

Epion Corporation is a supplier of ion and laser beam processing equipment and related services. Products include gas cluster ion beam systems, fullerene sublimators, diamondlike coating 
thermochemical equilibria; phase diagram CD-ROMs; software for prediction of glass and polymer properties; and software for rendering of crystal structures.

\section{- Charles Evans \& Associates}

301 Chesapeake Drive

Redwood City, CA 94063

Telephone: 415-369-4567

Fax: 415-369-7921

http://www.cea.com

Charles Evans \& Associates is a complete analytical service laboratory specializing in surface, trace-level, and microanalysis of materials. We have an outstanding analytical laboratory with SIMS, ESCA, Static SIMS, FTIR, SEM AUGER, RBS, AFM, and many other techniques for surface analysis. Our capabilities include measurement of trace-level impurities and dopants, characterization of thin or thick films, particle analysis, and failure analysis Stop by our booth to discuss your materials characterization requirements.

\section{- FEI Company \\ Components Group}

7451 NE Evergreen Parkway

Hillsboro, OR 97124-5830

Telephone: $503-844-2520$

Fax: 503-640-7509

The FEI Components Group is a leading supplier of focused electron and ion source products to major original equipment manufacturers worldwide. Our continuing commitment to research, combined with our direct contact with end-users, has established FEI Components Group as the leader in charged particle technologies.

Principle products include: - $\mathrm{LaB}_{6}$ electron sources - $\mathrm{CeB}_{6}$ electron sources

-Schottky electron sources

- Schottky emission electron columns

- Liquid metal ion columns

E.A. Fischione Instruments, Inc. 9003 Corporate Circle Export, PA 15632

Telephone: 412-325-5444

Fax: 412-325-5443

E-mail: paul.fischione@internetmci.com E.A. Fischione Instruments, Inc. features a complete line of TEM Specimen Preparation devices including the Model 3000 Ion Mill, the Model 330 Ultrasonic Disk Cutter, the Model 2000 Specimen Prep System (dimple grinder), and the Automatic Twin-Jet Electropolisher. New product introductions include the Model 1400 Plasma Cleaner for the elimination of contamination from both TEM specimens and TEM Specimen Holders. Also displayed are SEM and TEM Specimen Holders including the Cryo-Prep Station/TEM Holder.

\section{- Fujikin of America, Inc \\ 2028 E. Ben White Blvd.}

Suite 320

Austin, TX 78741

Telephone: 512-912-9095

Fax: 512-912-8095

E-mail: FTX001@ix.netcom.com

http://www.fujikin.com

Fujikin of American, Inc. is the leading manufacturer of valves and fittings for UHP gas panel applications. With an average internal surface finish of $2 \mu$ in.Ra, very low volume, space saving compact design and extremely low particle generation, our products can drastically reduce your purging, pumpdown and outgassing times in sub $0.25 \mu$ processes.

\section{- Gatan, Inc.}

6678 Owens Drive

Pleasanton, CA 94588

Telephone: 510-463-0200

Fax: 510-463-0204

http://www.gatan.com

Gatan, Inc. is the world's leading manufacturer of instrumentation and software used to enhance and extend the operation and performance of electronmicroscopes. Gatan's products, which are fully compatible with all brandselectron microscopes, cover the entire range of the analytical process from specimen preparation and manipulation to imaging and analysis. Our customer base spans the complete spectrum of end-users of analytical instrumentation typically found in industrial, governmental, and academic laboratories. The applications addressed by these scientists and researchers include metallurgy, semiconductors, electronics, biological science, new materials research and biotechnology. The Gatan brand name is very recognized and respected throughout the worldwide scientific community and has been synonymous with high quality products and the industry's leading technology.

High Voltage Engineering

P.O. Box 99

$3800 \mathrm{AB}$ Amersfoort

The Netherlands

Telephone: 31-33-4619741

Fax: 31-33-4615291

High Voltage Engineering, an engineering-oriented company, designs, manufactures, sells and markets custom-made, high-tech capital equipment for the world market.

Specializing in the development and manufacture of ion beam technologybased equipment, High Voltage Engineering is the largest and most diverse manufacturer of particle accelerator systems for the scientific, educational and industrial research communities. Major product lines include: Ion Accelerator Systems, Research Ion Implanters, Systems for Ion Beam Analysis, and various components such as HV power supplies, electron and ion accelerator tubes, ion sources, beamline components, beam monitoring equipment, etc.

(see ad in this issue)

\section{Huntington Mechanical}

Laboratories, Inc.

1040 L'Avenida Street

Mountain View, CA 94043-1422

Telephone: 415-964-3323

Fax: 415-964-6153

E-mail: huntvac.com

http://www.huntvac.com

The industry's largest selection of vacuum valves, flanges, fittings, and feedthroughs is available when you need it at Huntington. Also available are a wide assortment of roughing components including flexible hoses, traps, thermocouple and ionization gauge tubes, sorption and jet roughing pumps. Standard, custom, or modified $\mathrm{UHV}$ positioning and motion devices can be provided to meet your special needs. Stainless steel custom chambers, tees, and crosses are supported by a quarter of a century of experience in vacuum chamber design and fabrication at Huntington.

(see ad in this issue)
- Hysitron, Inc

2010 E. Hennepin Avenue

Minneapolis, MN 55413

Telephone: $612-379-4179$

Fax: 612-379-0678

E-mail: nanowyrobek@attmail.com

http://www.hysitron.com

Hysitron, Inc. is an engineering firm specializing in the design and manufacture of force and displacement transducers. Patents exist on its transducer technology and several creative applications. The current successful commercialization is for the nanomechanical community with a nanoindenter that stands alone or retrofits to atomic force microscopes. Features include in situ imaging of uitrashallow nano-indentation and nano-scratch.

\section{IBM Analytical and Test Services}

\section{Dept. 16W, MS/EM1}

1580 Route 52

Hopewell Junction, NY 12533

Telephone: 914-892-2627

Fax:914-892-2003

E-mail: Labs@vnet.ibm.com

Offers a broad range of capabilities from failure analysis to chemical and electrical characterization, all performed by a highly experienced staff of experts in their specific fields. We offer high-quality work performed on state-of-the-art equipment in a timely and cost-competitive environment.

Implant Sciences Corporation

107 Audubon Road, \#5

Wakefield, MA 01880

Telephone: $617-246-0700$

Fax: 617-246-1167

Implant Sciences offers ion implantation services with over 60 species available, including noble metals and rare earths. Heated implants and cryogenic implants done in research applications. Profile Code ${ }^{\mathrm{TM}}$ Software will be on display for accurate simulation of ion implantation. Pin-on disk friction and wear testing equipment also are available.

Inel, Inc.

P.O. Box 147

Stratham, NH 03885

Telephone: 603-778-9161

Fax: 603-778-9171

Inel specializes in manufacturing

unique $x$-ray diffractometer systems

with advanced detection capabilities.

Our instruments are equipped with

Position Sensitive Detectors (PSD)

which collect data simultaneously

with excellent resolution. We will

be exhibiting our Multi-Purpose

Diffractometer for thin-film

reflectometry, grazing angle and

powder diffraction.

INNOVAC Corporation

P.O. Box 3367

50 Harrison Street

Hoboken, NJ 07030

Telephone: 201-963-5450

Fax: 201-963-5449

E-mail: sales@innovac.com

INNOVAC provides various thin-film deposition equipment (sputtering evaporation and ion beam deposition). INNOVAC introduces OMNI-PVD 6000 by using Pfeiffer's PLS 500 box coater. INNOVAC will provide sputter guns, evaporator and ion beams as well as a customized sample holder at a very affordable price $(-\$ 200,000)$. INNOVAC also specializes in providing customized PVD systems.

Instron Corporation

100 Royall Street

Canton, MA 02021

Telephone: $617-828-2500$

Fax: 617-575-5751

Instron Corporation is a worldwide supplier of materials and component testing instruments, systems, software, and accessories used to evaluate the mechanical properties and performance of metals, plastics, composites, textiles, ceramics, rubber, biomedical, and adhesives. The Instron Family of products is available for all types of testing including: Fatigue, Hardness, Impact, and Tensile.

\section{$\$$ Instruments SA, Inc}

3880 Park Avenue

Edison, NJ 08820

Telephone: 908-494-8660

Fax: 908-549-2571

E-mail: Raman@ISAInc.com Instruments SA, Inc. is committed to serving our customers with superior products and technical support for optical spectroscopy. ISA offers many versatile research and low-cost Raman spectrometers as well as scanning and imaging spectrometer systems, fluorescence systems, ellipsometry, and 


\author{
IEOL USA, Inc. \\ P.O. Box 6043 \\ 11 Dearborn Road \\ Peabody, MA 01960 \\ Telephone: 508-535-5900 \\ Fax: 508-536-2205 \\ E-mail: eod@jeol.com \\ http://www.jeol.com \\ A $200 \mathrm{kV}$ FEG with better than $0.2 \mathrm{~nm}$ \\ point resolution in STEM; a $4.0 \mathrm{KUHV}$ \\ STM; a UHV AFM/STM with non- \\ contact, atomic resolution; a new \\ ambient/environmental SPM with \\ cold and hot stage; a new SEM with \\ $2.5 \mathrm{~nm}$ resolution and a new, really \\ intuitive user interface; all the other \\ high performance, reliable instruments \\ in the JEOL product line. Ask for more \\ information.
}

\section{k-Space Associates, Inc.}

555S. Forest Avenue, Suite 4B

Ann Arbor, MI 48104

Telephone: 313-668-4644

Fax: 313-668-4663

E-mail: kspace@dial.cic.net

k-Space manufactures the KSA 300

family of turn-key RHEED and LEED imaging systems. A peltier-cooled integration selectable CCD imager, realtime acquisition, and 32-bit NT/'95 software for point and click analysis of strain, FWHM, and FFT/growth rate are just a few of the reasons we put the power of RHEED and LEED at your fingertips.

Keithley Instruments, Inc

\section{Aurora Road}

Solon, OH 44139

Telephone: 216-248-0400

Fax:216-248-6168

E-mail: product info@keithley.com

http://www.keithley.com

Keithley will display its line of sensitive test instrumentation designed for materials research applications.

Included will be the Model 6517 highresistance measurement system with outstanding high-resistance measurement capability $(100 \mathrm{~m} \Omega)$ and superior low current measurements (100 aA to $20 \mathrm{~mA}$ ). Also on display will be the Model $2485 \mathrm{kV}$ low noise power supply and the Model 2400 Digital

SourceMeter ${ }^{\mathrm{TM}}$

Kevex X-Ray Inc.

320 El Pueblo Road

Scotts Valley, CA 95066

Telephone: 408-438-5940

Fax: 408-438-5892

Kevex X-Ray will display its line of microfocus $x$-ray tubes, portable $x$-ray sources (PXS), and high-stability $x$-ray tubes.

Kluwer Academic Publishers

101 Philip Drive

Norwell, MA 02061

Telephone: $617-871-6600$

Fax: 617-871-6528

E-mail: kluwer@wkap.com

http:/ / www.wkap.n

Kluwer Academic Publishers is a leading research publisher of books and journals in materials sciences. New books are on display, along with such journals as Applied Composite Materials Advanced Performance Materials; the Journal of Porous Materials; Interface Science; Adsorption and the Journal of Sol-Gel Technology.
Lake Shore Cryotronics, Inc.

64 E. Walnut Street

Westerville, OH 43081

Telephone: 614-891-2243

Fax: 614-891-1392

E-mail: sales@lakeshore.com

http://www.lakeshore.com

Integrated Hall effect and magnetoresistance semiconductor material characterization systems with Van der

Pauw resistivity measurements and features QMSA, a new data-manipulation algorithm which simultaneously derives concentrations and mobilities for multiple distributions of electrons and holes in layered semiconductor device structures. Also vibrating sample magnetometers, AC susceptometers / DC magnetometers, cryogenic platforms, high level, Windows ${ }^{\mathrm{TM}}$

based instrument management software, new Model 340 temperature controller with multiple sensor inputs, cryogenic temperature sensors,

gaussmeters, Hall generators,

electromagnets, and four-quadrant power supplies

\section{- Lambda Technologies}

8900 Jersey Court, Suite C

Raleigh, NC 27613

Telephone: $919-420-0275$

Fax:919-420-0095

E-mail: lambda@vari-wave.com

http:/ /www.vari-wave.com

Lambda Technologies employs variable frequency microwave concepts to provide uniform and controlled heating over large volumes with efficient and selective energy coupling. Lambda's proprietary technology has been applied in areas of polymer and composite processing, bonding of dissimilar materials, encapsulant and epoxy curing, ceramic sintering, surchemical reaction enhancement.

Lasertec U.S:A., Inc.

1778 Technology Drive

San Jose, CA 95110

Telephone: 408-437-1441

Fax: 408-437-1430

Lasertec's Confocal Laser Scanning

Microscopes display high-resolution images in real time. The excellent resolution and focus scan memory allow depth measurements to be made very accurately. Applications include semiconductors, magnetic heads, glass ceramics, laser disks, metal surfaces, plastics, paper, and copier drums.

\section{$\checkmark$ Kurt I. Lesker Company}

1515 Worthington Avenue

Clairton, PA 15025-2700

Telephone: 412-233-4200

Fax: 412-233-4275

E-mail: sales@lesker.com

http:/ / www.lesker.com

We are exclusive North American

agents for Vacuum Generators and VG

Microtech, displaying their economical high precision $X Y Z$ manipulators, unique UHV sample distribution center and their surface science components for XPS, AES, UPS, LEED, and RHEED. We will show our manufacturing capability for high vacuum and UHV custom chambers together with flanges, hardware, electrical and rotary feedthroughs.
LUXTRON Corporation

2775 Northwestern Parkway

Santa Clara, CA 95051-0941

Telephone: 408-727-1600

Fax: 408-727-1677

Optical fiber temperature measure-

ment and control instrumentation.

Offers non-contact and contact tem-

perature measurement from $-200^{\circ} \mathrm{C}$ to

$4000^{\circ} \mathrm{C}$ with resolution to $0.01^{\circ} \mathrm{C}$.

Magnet Sales \& Manufacturing

11248 Playa Court

Culver City, CA 90230

Telephone: 310-391-7213

Fax: 310-390-4357

Design and manufacture of high-grade permanent magnets and assemblies.

We offer magnetic finite element design assistance, a large inventory of permanent magnet materials and a complete in-house magnet and metal working machine shop. We specialize in small quantities and short lead times as well as complex and developmental designs.

MARCH Instruments, Inc.

4057 Port Chicago Highway

Concord, CA 94520

Telephone: $510-827-1240$

Fax: 510-827-1189

E-mail: march@plasmod.com

http:/ /www.plasmod.com

Featuring a new in-line plasma cleaning system enabling interfacing with any conveyor process: boards, panels, boats, or cassettes. A small section of a standard conveyor allows the product to move from the previous station into the MARCH plasma systems and into the next station. This system is microprocessor and/or PC controlled.

\section{- Materials Analysis Group}

Philips Semiconductors MS 65

$811 \mathrm{E}$. Arques Avenue

Sunnyvale, CA 94088

Telephone: 408-991-4868

Fax: 408-991-4801

E-mail: morgana@scs.philips.com

Analytical services laboratory offering

SIMS, GDMS, FIB, Auger, ESCA, RBS,

AFM/SPM, TEM, FESEM, EDX, XRF,

XRD, Raman, FTIR, UV/Vis,

GC/MS/IR, GPC, ICP IC

TGA/TMA/DSC, and acoustic microscopy for surface, interface, particle, thin film and bulk materials characterization. Trace element detection, high-resolution imaging and depth profiling, and precision cross-sectioning.

- MDC Vacuum Products Corporation 23842 Cabot Blvd

Hayward, CA 94545

Telephone: $510-265-3500$

Fax: 510-887-0626

E-mail: sales@mdc-vacuum.com

http://www.mdc-vacuum.com Complete line of UHV components including: flanges and fittings, valves, roughing components, instrumentation, electrical feedthroughs, XYZ manipulators, rotary and linear feedthroughs, fast-entry load-lock systems, all-metal sealed right angle valves and M.E.S.A. compatible rectangular gate valves. A complete line of electron beam evaporation sources in single-pocket and multi-pocket configuration with matching $6 \mathrm{kw}, 10 \mathrm{kw}$, and $15 \mathrm{kw}$ solid-state switching power supplies.

(see ad in this issue)

Micro Photonics Inc

4949 Liberty Lane, Suite 160

P.O. Box 3129

Allentown, PA 18106-0129

Telephone: $610-366-7103$

Fax: 610-366-7105

E-mail: surftest@aol.com

http://www.microphotonics.com

Micro Photonics supplies Surface Test instruments for indentation hardness testing, scratch adhesion testing, wear testing, non-contract surface profiling and dynamic single fiber testing; Thin Film Analysis/Endpoint Detection instruments utilizing ellipsometry, interferometry and $\mathrm{OES}$; and CCD

Cameras for low-light imaging applications in the physical and life sciences.

- MMR Technologies, Inc.

1400 N. Shoreline Blvd Suite A-5

Mountain View, CA 94043-1346

Telephone: 415-962-9620

Fax: 415-962-9647

E-mail: bobp@mmr.com

http://www.mmr.com

MMR Technologies manufactures temperature controlled systems-cryogenic cooling systems and wide temperature range thermal stages-which find application in materials research in electrical engineering, physics, biology and chemistry applications over the temperature range of $10 \mathrm{~K}$ to $730 \mathrm{~K}$ They are also used in the cooling of computer chips, electronic devices, laser diodes, and thermal imaging devices, and in the characterization of the performance and properties of such devices as a function of temperature.

(see ad in this issue)

- Molecular Simulations, Inc.

8585 Scranton Road

San Diego, CA 92121

Telephone: $619-458-9990$ 
National Electrostatics Corporation P.O. Box 620310

7540 Graber Road

Middleton, WI 53562-0310

Telephone: $608-831-7600$

Fax: 608-256-4103

E-mail: nec@well.com

National Electrostatics Corporation manufactures a wide variety of ion beam systems from below $100 \mathrm{keV}$ to the hundreds of $\mathrm{MeV}$ region. These systems include complete materials analysis systems using $\mathrm{MeV}$ ion beams. NEC also manufactures a wide range of beam handling and vacuum. components including vacuum isolators for vacuum pumps.

- Neocera, Inc.

10000 Virginia Manor Road, Suite 300

Beltsville, MD 20705-4215

Telephone: 301-210-1010

Fax: 301-210-1042

Specialists in pulsed laser deposition (PLD) and advanced thin film technologies, Neocera will be exhibitin and demonstrating a fully operationa PLD vacuum system. Also displayed will be different PLD accessories and custom metal oxide films deposited on a variety of substrates. Please stop by our booth to discuss PLD and its applications, our unique R\&D efforts, products and services.

\section{New Focus, Inc.}

Santa Clara CA 95051-0905

Telephone: 408-980-8088

Fax: 408-980-8883

E-mail: Contact@NewFocus.com

http://www.NewFocus.com2

Award-winning building blocks for sensing, diagnostics and process control featuring external-cavity tunable diode lasers, multipass absorption cells, differential optical receivers, modulators, ultrahigh-speed photodetectors, and optical components. Laser tools include ultrastable positioners featuring our new compact mounts and high-resolution Picomotors (all available in a vacuum compatible version). Stop by our booth at the MRS Spring Meeting or give us a call for a free catalog. (see ad in this issue)

Nicolet Instrument Corporation 5225 Verona Road

Madison, WI 53711

Telephone: 608-276-6100

Fax: 608-273-5046

E-mail: nicinfo@nicolet.com

http://www.nicolet.com

Nicolet will exhibit the compact

Protégé 460 spectrometer with powerful OMNIC software. The FT-IR spectrometer system utilizes DSP technology to provide performance, efficiency and serviceability in an affordable FT-IR system. It offers increased flexibility when coupled with the InspectIR FT-IR Microsampling and Video Imaging Accessory.

Noranda Advanced Materials

4950 Levy Street

St. Laurent, Quebec H4R 2P1

Canada

Telephone: 514-856-6956

Fax: 514-856-6925

E-mail: bensonm@advmat.noranda.com

Noranda Advanced Materials man-

ages new product initiatives of

Noranda's metallurgical operations

We develop, produce and sell world-

competitive and innovative products

based on Noranda's technical resources, production capabilities and markets. We produce ultra-pure metals for semiconductor, thermoelectric and photoreceptor markets. We are also leaders in the development and production of selenium-based detectors for digital radiography.

- Nor-Cal Products, Inc

1967 S. Oregon Street

P.O. Box 518

Yreka, CA 96097

Telephone: 916-842-4457

Fax: $916-842-9130$

E-mail: norcal@n-c.com

http://www.n-c.com

Manufacturer of stainless steel vacuum components for over 30 years. Standard products include: NW, ISO, ASA, CF, and Wire Seal flanges; fittings, viewports feedthroughs and flexible hoses; manual and pneumatically actuated valves; liquid nitrogen, molecular sieve, water-cooled, and particulate foreline traps; and high vacuum and UHV manipulators. Custom chambers, manifolds, feedthrough collars and baseplates can be manufactured from customer specifications, sketches or drawings.

\section{Omicron Associates}

1738 N. Highland Road

Suite G101

Pittsburgh, PA 15241

Telephone: 412-831-2262

Fax: 412-831-9828

E-mail:OmiAssoc@aol.com

In addition to the World's most powerful UHV analytical instrument combining SEM and SAM with Scanning Probe Microscopy, in 1997 OMICRON will introduce a new LEED/AES control system, new CMA150 analyzer new PEEM and new HREELS instrument. These developments compliment the present award-winning UHV SPM instruments, and allow OMICRON to offer the most comprehensive and unique, multi-technique analytical systems available for materials research.

\section{Oxford Applied Research}

Crawley Mill

Witney

Oxfordshire OX85T]

United Kingdom

Telephone: 44-1993-773575

Fax: 44-1993-70232

E-mail: sales@oxfordar.demon.co.uk Manufacturers of scientific instruments for thin film research. Our range of RF and thermal crackers facilitate: GaN growth: ZnSe p-doping: in situ substrate cleaning: Atomic $\mathrm{As}$, $\mathrm{Se}, \mathrm{S}$ for doping and bulk material growth Oxidation. Other products include RHEED, mini e-beam evaporators and electron guns for cleaning and beam neutralization.

Oxford Instruments, Inc Scientific Research Division 130A Baker Avenue Ext.

Concord, MA 01742

Telephone: 508-369-9933

Fax: 508-369-6616

E-mail: ferguson@oxford.usa.com

Visit Oxford Instruments' stand to find out about the latest integrated measurement systems, including the MagLab System 2000, designed for transport, thermal and magnetic measurements. Also discover our new STM instruments, including the MiniCryoSTM, designed for operation at temperatures down to $1.5 \mathrm{~K}$ and in magnetic fields within MagLab systems. A variety of Teslatron Superconducting Magnet systems are also available to explore the "BT" environment to 20 Tesla and $5 \mathrm{mK}$.

Park Scientific Instruments

Sales Department, M/S 249

1171 Borregas Avenue

Sunnvvale, CA 94089-1306

Telephone: 408-744-3049

Fax: 408-747-1601

E-mail: tjohnson@park.com

http://www.park.com

Park Scientific Instruments presents a complete family of Scanning Probe Microscopes including Autoprobe M5, the first fully integrated SPM to offer both atomic resolution and large sample capacity; the Autoprobe $\mathrm{CP}$, an affordable, full featured SPM; the Autoprobe SA, a portable, multi-mode AFM; Autoprobe VP2, a technically advanced and versatile UHV-SPM system; and our exclusive, prealigned cantilever assemblies available for a wide variety of applications.

- Parke Mathematical Laboratories

450 Chelmsford Street

Lowell, MA 0185

Telephone: 508-934-0854

Fax: 508-934-0731

E-mail:pml@parkemath.com

http:/ wrow parkemath.com

PML applies its expertise towards the development of solid-state materials and processes. These R\&D efforts have primarily been in support of defenserelated programs. In addition to its R\&D projects, Parke also provides consulting services to private industry, including furnace design for crystal growth, and is a producer of electronic-grade red phosphorus and $\mathrm{GaN}$ powder.

(see ad in this issue)

- Philips Electronic Instruments Company

85 McKee Drive

Mahwah, NJ 07430

Telephone: 201-529-6246

Fax: 201-529-508

http://www.philips.com/axr

Shilips Electronic Instruments

Company is the world's leading supplier of instrumentation and software for $\mathrm{XRD}$ and $\mathrm{XRF}$ analytical $\mathrm{x}$-ray equipment as well as a full line of SEM and TEM microscopes. Our philosophy is to provide targeted solutions to customer's application needs in markets as diverse as materials research cement, metals, pharmaceuticals and semiconductors. Our product lines includes the X'Pert MRD, PW2400,

PLM-100, XL30 and XL40.

(see ad in this issue)

Physical Electronics, Inc

6509 Flying Cloud Drive

Eden Prairie, MN 55344

Telephone: $612-828-6100$

Fax: 612-828-6322

E-mail: marketing@phi.com

http://www.phicom

Physical Electronics (PHI) develops, manufactures and markets surface analysis instrumentation to perform Auger Electron Spectroscopy (AES) X-ray Photoelectron Spectroscopy (XPS) Secondary Ion Mass Spectrometry (SIMS) and Time of Flight SIMS. These techniques characterize the top few atomic layers of a surface, providing spatiaily resolved information about elemental composition, chemical bonding and molecular structure

- Plasma Sciences, Inc

7200A Telegraph Square Drive

Lorton, VA 22079

Telephone: 703-550-7888; 800-207-9776 Fax:703-339-9860

E-mail: PLASMASCI@aol.com Plasma Sciences, Inc. specializes in the manufacture of planar magnetron thin-film deposition systems for research and pilot production. Multiple source DC/RF sputtering systems with recipe drive PC control re available as well as manual costeffective sputtering systems for smaller development applications. Other products include R\&D scale Broad Beam Ion Source systems, Reactive Ion Etchers, RF Ion Sources, and Planar Magnetron sources.

Plasmatron Coating Sytems, Inc.

102 Executive Drive, Unit 5

Moorestown, NJ 08057

Telephone: 609-439-099

Fax: 609-439-9288

E-mail: GWilliams@plasmatron.com

Plasmatron offers a complete range of high and ultra-high vacuum thin-film coating systems. All systems are custom engineered to address the specific requirements of each application and can include a variety of deposition equipment, including: magnetron sputtering, thermal and electron beam evaporation, cathodic arc, ion beam sputtering, laser ablation and chemica 
The systems manufactured and marketed by QualiTau allow simultaneous testing of devices and provide powerful data analysis tools

\section{$\$$ Research and PVD Materials Corporation \\ Wayne, NJ 07474 \\ Telephone: 201-575-4245 \\ Fax: 201-575-6460 \\ Research and PVD Materials \\ Corporation manufactures a wide variety of highly characterized, high purity materials for the diverse and sophisticated requirements of the semiconductor, electronics, electro- optic and related research communi- ties. Products from this single-quality source include but are not limited to sputtering targets, thin-film deposition materials, fabricated forms of specialty and exotic metals, alloys, ceramics, intermetallics, custom fabrications and "one off" components.}

Renishaw Inc.

623 Cooper Court

Schaumburg, IL 60173

Telephone: 847-843-3666

Fax: 847-843-1744

Renishaw will feature our revolutionary design Raman microscope which combines holographic notch filter and CCD technology to provide spectroscopy and fast direct 2-D Raman imaging in one unit for both fundamental research and quality assurance. The system provides high throughput $(>25 \%)$, resolution and sensitivity as well as $1 \mu \mathrm{m}$ spatial resolution and ful wavenumber spectra range $(-3000$ to

$7000 \mathrm{~cm}^{-1}$ ) with no spectral stitching. Developments include: new stable 780 nm laser diode system, fiber-optic probe, and GRAMS-based software system for low-cost process line and QA Raman

\section{- Rigakw/USA, Inc. \\ 199 Rosewood Drive \\ Danvers, MA 01923 \\ Telephone: 508-777-2446 \\ Fax: 508-777-3594 \\ E-mail: Rigaku@aol.com}

Rigaku has been one of the leaders in $X$-ray analytical instrumentation for more than 50 years and continues at the leading edge of $X$-ray analysis. Rigaku provides a wide range of equipment for $X$-ray diffraction and $X$-ray fluorescence which can be used for many different applications.

\section{SC Technology/Telemark \\ 51 Whitney Place}

Fremont, CA 94539

Telephone: $510-770-0900$

Fax: 510-770-1061

E-mail: GaryH@sctec.com

SC: In situ Multi-Wavelength Plasma Diagnostic and Endpoint Instruments. In situ Instruments to measure reflectivity, film thickness, and develop rate on track coaters. TELEMARK

Evaporation Sources, Power Supplies, Quartz Crystal Controllers, Optical

Monitors, Sputter Components, Wafer Services including Stepper

Lithography to .25 micron.

\section{- SensArray Corporation}

3410 Garrett Drive

Santa Clara, CA 95054-2803

Telephone: 408-727-4656

Fax: 408-496-6929

E-mail: info@sensarray.com

SensArray Corporation manufactures

instrumented wafers and glass substrates for direct measurement of temperature profiles inside process chambers. Also manufactures Therma Map 2, computer-based temperature mapping systems for data acquisition and analysis. Temperature range $-200^{\circ} \mathrm{C}$ to $1300^{\circ} \mathrm{C}$ for RTP, CVD, Photoresist, Diffusion/Oxidation, Sputter Deposition Systems and AMLCD processes.

\section{SKION Corporation}

P.O. Box 3367

50 Harrison Street

Hoboken, NJ 07030

Telephone: 201-963-5450

Fax: 201-963-5449

E-mail: sales@skion.com

SKION introduces a revolutionary

Metal Ion Beam Deposition Process.

Unlike other recent secondary means of energy enhancement in thin-film deposition techniques, the Metal Ion Beam Deposition process provides a direct energy transfer. The technique has demonstrated various application such as amorphous diamond coating on computer hard disks, hetero-epitax ial growth, field emission display, and synthesis of a new meta-stable material.

\section{- South Bay Technology, Inc.}

\section{Via Callejon}

San Clemente, CA 92673

Telephone: 800-728-2233; 714-492-2600

Fax: 714-492-1499

E-mail: sbt@southbaytech.com

http://www.southbaytech.com South Bay Technology, Inc. will be exhibiting the industry's most advanced sample preparation systems and supplies.

Featured will be sustems for:

- Plasma Cleaning for TEM

- Orienting, Cutting and Polishing Single Crystals

- Ultra-precise thinning of cross-section TEM samples

- Selective etching of GaAs/AlGaAs Heterostructures

- Damage-free cutting and polishing of soft single crystals

Featured products include:

- PC150 Plasma Cleaner built under license from Argonne National Laboratory pursuant to their (U.S. Patent 5,510,624) inventor Dr. Nestor J. Zaluzec

- IV3 Research Grade Ion Milling System for TEM, SEM and Optical Microscopy

- Tripod ${ }^{\mathrm{TM}}$ Polisher, BiPod ${ }^{\mathrm{TM}}$ Polisher for TEM and SEM Polishing

- 900 Series Lapping and Polishing Systems

- Real-time Back Reflection Laue

Camera

Application engineers will be on hand to help you solve your most difficult sample preparation problems. For further information, please contact us by telephone at 800-728-2233; fax at 714-492-1499; E-mail at sbt@southbaytech.com

SPI Supplies/Structure Probe, Inc. P.O. Box 656

569 E. Gay Street

West Chester, PA 19381-0656

Telephone: $610-436-5400$

Fax: 610-436-5755

E-mail: spi2spi@2spi.com

http://www.2spi.com

Structure Probe, Inc. is an independent laboratory providing innovative elec- tron microscopy and surface analysis services for solving materials science problems including HTC materials diamond coatings and complex polymer systems. SPI Supplies: Sample preparation instruments and consumable supply items for electron microscopy and surface analysis laboratories. Exclusive SPI-Module ${ }^{\mathrm{TM}}$

Sputter/Carbon Coating System Plasma Prep II ${ }^{\mathrm{TM}}$ etcher/asher, Plasm Prep $X^{\mathrm{TM}}$ Parallel Plate all solid state

Plasma Etcher for anisotropic etching and "Tacky Dot" slides.

\section{$\downarrow$ STAIB Instruments, Inc.}

813 Diligence Drive, \#121 E

Newport News, VA 23606

Telephone: 757-873-0099

Fax: 757-873-0130

E-mail: staibinstruments@worldnet.att.net Manufacturers of compact, high-performance electron-optical equipment for in-situ material analysis, including: RHEED systems, analyzer, and data acquisition to study structure and quality of thin films; Photo-Emission Electron Microscopes (PEEM), for dynamic studies of chemical distribution with high time and space resolution; Auger spectrometers; and Electron Guns for analytical surface studies.

\section{SURFACE}

Rheinstrasse

D-41836 Hueckelhoven

Germany

Telephone: 49-2433-970305

Fax: 49-2433-970302

E-mail: surface@compuserve.com

SURFACE is working since years in the field of plasma-related technologies. The developments of the last years were focused to the Large Area Pulsed Laser Deposition and the design and manufacturing of such equipment. A family of high-flexible process systems is available. From inexpensive systems for max. $1^{\prime \prime}$ samples up to high-complex $4^{\prime \prime}$ multichamber semiproduction systems SURFACE offers the widest range of PLD systems on the market. As a new technology, Large Area Laser

Annealing Systems are available, used for different applications like flatpanel displays, sol-gel coatings and ceramics.

- Surface/Interface, Inc.

110 Pioneer Way, Suite D

Mountain View, CA 94041

Telephone: $415-965-8205$

Fax: 415-965-8207

E-mail: sii@surfaceinterface.com

Surface/Interface provides innovative product solutions to meet the needs of ultrahigh vacuum, semiconductor manufacturing and surface analysis customers. S/I specializes in "ultraclean" components and UHV-compatible motors for analytical systems and vacuum and manufacturing applications. $S$ /I also offers highly pure, characterized reference materials and custom products and consulting services to industry and the materials science community.

\section{- SVT Associate}

7620 Executive Drive

Eden Prairie, MN 55344

Fax: 612-934-2737

E-mail: svta@svta.com

Manufacturer of leading deposition and process monitoring equipment for

III-V MBE and UHV/CVD Si-Ge materials research. SVTA offers a new III-Nitride MBE system with guaranteed material specifications, and a complete line of effusion cells, RF Plasma Sources, Compact E-Beam Sources, and other sources, and Pyro Metric Interferometer RHEED, and Cathodoluminescence instruments. We also provide epi-wafer research and service.

(see ad in this issue)

TECHNOTRADE International, Inc.

7 Perimeter Road

Manchester, NH 03103

Telephone: 603-622-5011

Fax: 603-622-5211

Representing the following products:

BAL-TEC-sample preparation systems and accessories for electron

microscopy featuring the RES 010 Ion Milling System; MECO-chain clamps and metal seals for all $\mathrm{HV}$ and $\mathrm{UHV}$ applications; SASKIA-oil-free diaphragm and piston pumps; WOLF-UHV instrument feedthroughs utilizing sub " $\mathrm{D}$ " connectors.

Tencor Instruments

One Technology Drive

Milpitas, CA 95035

Telephone: 408-571-3000

Fax: 408-571-3030

E-mail: judy.dale@tencor.com 
Thermionics Laboratory, Inc.

22815 Sutro Street

P.O. Box 3711

Hayward, CA 94540-3711

Telephone: 510-538-3304

Fax: 510-538-2889

E-mail: sales@thermionicscorp.com

http://www.thermionics.com

Thermionics manufactures vacuum systems, components, and hardware for all vacuum applications including: DRS $^{\top \mathrm{M}}$, an in-situ, remote substrate temperature measurement/control system; 3-20 kW e-Gun ${ }^{\mathrm{TM}}$ evaporation sources and power supplies; Ion pumps, titanium sublimators; $X Y Z$ manipulators, sample handling and transfer devices, differentially pumped rotary seals; gate, angle and all metal valves; feedthroughs, gauges and controls, flanges, fittings; surface science, deposition, PLD, R-HEED, and custom systems.

$\$$ TopoMetrix Corp.

5403 Betsy Ross Drive

Santa Clara, CA 95054-1162

Telephone: 408-982-9700

Fax: 408-982-9751

E-mail: garyw@topometrix.mhs. compuserve.com

http:// www.topometrix.com

TopoMetrix manufactures Scanning

Probe Microscopes (Scanning

Tunneling, Atomic Force and Near-

field Scanning Optical Microscopes)

for sales worldwide. It produces a

large range of probe stages for the analysis of both large and small samples. The company has field offices worldwide for sales, applications development and support.

\section{- Union Carbide Crystal Products \\ 750 South 32nd Street \\ Washougal, WA 98671 \\ Telephone: 360-835-2001 \\ Fax: 360-835-9848}

Crystal Products, located in the Pacific

Northwest, offers Czochralski-grown Sapphire substrates for blue LED, superconductors, and SOI, radiationhardened, IC devices. Sizes are 2" and $3^{\prime \prime}$ diameter, C-plane; $2^{\prime \prime}$ to $6^{\prime \prime}$ diameter, R-plane; and SOS epitaxial wafers. See our Sapphire Research Kits containing substrates oriented to M, A, R $\&$ C axes.

Vacuum Atmospheres Co. P.O. Box 1043

4652 West Rosecrans Avenue

Hawthorne, CA 90250-6896

Telephone: 310-644-0255

Fax: 310-970-0980

E-mail: sales@vac-atm.com

http://www.vac-atm.com

Vacuum Atmospheres Co. manufactures inert atmosphere glove boxes, gas purification systems and trace gas analysis equipment. Applications include inorganic chemistry, crystallography, organometallic chemistry, solid state chemistry. Custom designs for isolation barriers used in battery, semi-conductor, pharmaceutical, and laser applications.

Varian Vacuum Products

3120 Hansen Way

M/S D-104

Palo Alto, CA 94304

Telephone: 415-424-5824; 800-882-7426

Fax: 617-860-5437

Varian Vacuum Products will exhibit a

broad range of high vacuum equip- ment including the MacroTorr, maintenance-free ceramic-bearing turbo pump and the Starcell ${ }^{(B)}$ Ion Pump. On display will be a dry turbo pump station, a model 956 Turbo Leak Detector and the new sen Torr ${ }^{\mathrm{TM}}$ Gauge Controller.

VCR Group, Inc.

South San Francisco, CA 94080

Telephone: 415-875-1000

E-mail: vcrvince@aol.com

See it! XLA/2000 Ion Mill, PC-based:

data set-up, record logging and scheduling...Larger electron transparent areas, one- or two-sided, low-angle milling $\left(54^{\circ}\right)$, and adjustable ion beam striking position. DIMPLER ${ }^{(\mathbb{B})}$, D500i-

Robotic, automatic, low-angle dimpling. IBS/TM200S8A Cr films without $\mathrm{Cr} X$-ray peak! Unobservable

ultrathin metal films: Ta, W, Ir, Pt and carbon.

- Virginia Semiconductor, Inc.

1501 Powhatan Street

Fredericksburg, VA 22401

Telephone: $540-373-2900$

Fax: 540-371-0371

Featuring Ultrathin ${ }^{\mathrm{TM}}$ and

Ultramachining ${ }^{\mathrm{TM}}$ silicon wafers with flatness $\leq 3 \mu$, planarity of $\leq 3 \mu$, and taper $\leq 2.5 \mu$; also offering back side polishing services, custom or research wafer and ingot preparations, and conventional small diameter single and double side polished $\mathrm{Cz}$ or $\mathrm{Fz}$ wafers. For precisely engineered silicon products. "If we can't make it, you don't need it!"

(see ad in this issue)
250 E. Grand Avenue, Suite \#70

Fax: 415-875-7111

Voltaix, Inc

197 Meister Avenue

P.O. Box 5357

North Branch, NJ 08876

Telephone: 908-231-9060

Fax: 908-231-9063

http://www.voltaix.com

Voltaix, Inc. manufactures and distributes gases used for CVD and ion implantation applications including diborane, germane, trimethylboron and methylsilane. These gases, as well as silane, phosphine, silicon and germanium tetraftuoride and boron trifluoride are available as pure gases and in a variety of mixtures. We also supply isotopically enriched versions (e.g. $\left.{ }^{10} \mathrm{~B},{ }^{11} \mathrm{~B},{ }^{29} \mathrm{Si}, \mathrm{D}\right)$ of most of our gases, which have shown promise in ion implantation and CVD applications. (see ad in this issue)

Yasui Seiki Co., (USA)

2333 Industrial Drive

Suite 24A3

Bloomington, IN 47404

Telephone: 812-331-0700

Fax: 812-331-2800

E-mail: yasui@ix.netcom.com

http:/ www.yasui.com

Yasui Seiki Co. (USA) is a subsidiary of Yasui Seiki Co., Ltd. of Kanagawa, Japan. High precision coating machines are provided for electronic materials, imaging films and papers, display devices and other high-tech applications. Coating laboratories in Japan and Bloomington, IN serve hundreds of companies each year with product and process research.

970018

Are you planning a conference or short course?

Promoting books or journals?

Announcing your latest software?

A mailing list from the Materials Research Society is exactly what you need! over 140,000 names of scientists and research managers who are active in forefront areas of materials research and engineering. Lists are grouped in four main categories:

- Materials by application

- Materials by properties

- Materials characterization

- Materials processing

MRS Mailing List Rental... ...reaching the broadest range of materials professionals directly!

Offer expires April 30, 1997

Contact Mary E. Kaufold today at 412-367-3036 to place your ads. 


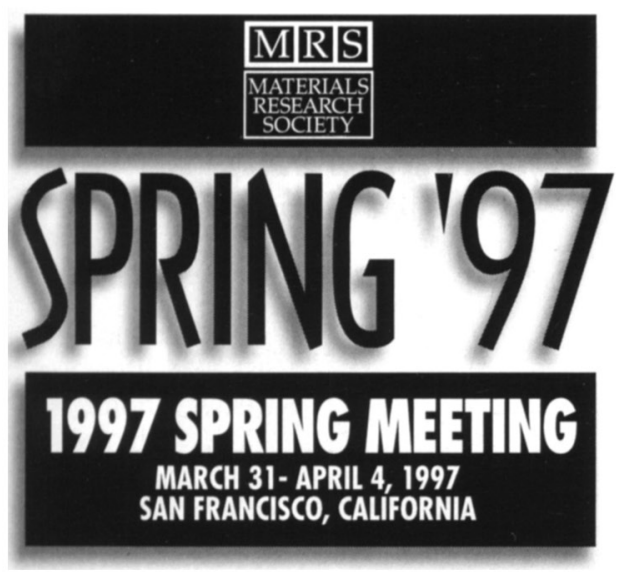

Special pre-meeting prices effective until April 15, 1997.

After April 15, 1997,

pay the higher prices on the right.

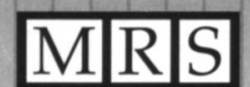

MATERIALS

RESEARCH SOCIETY

\section{Materials Research Society}

9800 McKnight Road

Pittsburgh, PA 15237

Phone: 412-367-3012

Fax: 412-367-4373

E-mail: info@mrs.org

www.mrs.org/publications/books/iorms/

Forthcoming from MRS at special pre-meeting prices...

1997 Spring Meeting

Symposium Proceedings

Place your order today for proceedings of the 1997 MRS Spring Meeting in San Francisco and SAVE!

A: Amorphous and Microcrystalline Silicon Technology-1997

Editors: E.A. Schiff, M. Hack, S. Wagner, R. Schropp, I. Shimizu

ISBN: $1-55899-371-1$ Code: 467-B

$\begin{array}{lll}\$ 52.00 & \$ 62.00 & \text { MRS Member } \\ \$ 60.00 & \$ 71.00 & \text { U.S. List } \\ \$ 69.00 & \$ 82.00 & \text { Non-U.S. }\end{array}$

D: Gallium Nitride and Related Materials II

Editors: C.R. Abernathy, H. Amano, J.C. Zolper

ISBN: 1-55899-372-X Code: 468-B

$\begin{array}{lll}\$ 52.00 & \$ 62.00 & \text { MRS Member } \\ \$ 60.00 & \$ 71.00 & \text { U.S. List } \\ \$ 69.00 & \$ 82.00 & \text { Non-U.S. }\end{array}$

E: Defects and Diffusion in Silicon Processing

Editors: S. Coffa, T. Diaz de la Rubia, P.A. Stolk, C.S. Rafferty

ISBN: 1-55899-373-8 Code: 469-B

$\begin{array}{lll}\$ 55.00 & \$ 65.00 & \text { MRS Member } \\ \$ 63.00 & \$ 75.00 & \text { U.S. List } \\ \$ 73.00 & \$ 86.00 & \text { Non-U.S. }\end{array}$

F: Rapid Thermal and Integrated Processing VI

Editors: T.J. Riley, J.C. Gelpey, F. Roozeboom,

S. Saito

ISBN: 1-55899-374-6 Code: 470-B

$\begin{array}{lll}\$ 52.00 & \$ 62.00 & \text { MRS Member } \\ \$ 60.00 & \$ 71.00 & \text { U.S. List } \\ \$ 69.00 & \$ 82.00 & \text { Non-U.S. }\end{array}$

G: Flat Panel Display Materials III Editors: R. Fulks, G. Parsons, D. Slobodin,

T. Yuzuriha

ISBN: 1-55899-375-4 Code: 471-B

$\begin{array}{lll}\$ 52.00 & \$ 62.00 & \text { MRS Member } \\ \$ 60.00 & \$ 71.00 & \text { U.S. List } \\ \$ 69.00 & \$ 82.00 & \text { Non-U.S. }\end{array}$

I: Polycrystalline Thin Films-Structure, Texture, Properties and Applications IIl Editors: J. Im, S. Yalisove, B. Adams, Y. Zhu,

F-R. Chen

ISBN: 1-55899-376-2 Code: 472-B

$\begin{array}{lll}\$ 55.00 & \$ 65.00 & \text { MRS Memb } \\ \$ 63.00 & \$ 75.00 & \text { U.S. List } \\ \$ 73.00 & \$ 86.00 & \text { Non-U.S. }\end{array}$

$\mathrm{J}$ : Materials Reliability in

Microelectronics VII

Editors: J.J. Clement, J. E. Sanchez, Jr., K.S. Krisch, Z. Suo, R.R. Keller

ISBN: 1-55899-377-0 Code: 473-B

$\begin{array}{lll}\$ 55.00 & \$ 65.00 & \text { MRS Member } \\ \$ 63.00 & \$ 75.00 & \text { U.S. List } \\ \$ 73.00 & \$ 86.00 & \text { Non-U.S. }\end{array}$

L: Epitaxial Oxide Thin Films III

Editors: C. Foster, J.S. Speck, D. Schlom, C-B. Eom,

M.E. Hawley

ISBN: $1-55899-378-9$ Code: 474-B

$\begin{array}{lll}\$ 55.00 & \$ 65.00 & \text { MRS Member } \\ \$ 63.00 & \$ 75.00 & \text { U.S. List } \\ \$ 73.00 & \$ 86.00 & \text { Non-U.S. }\end{array}$

M: Magnetic Ultrathin Films, Multilayers and Surfaces-1997

Editors: D.D. Chambliss, J.G. Tobin, D. Kubinski,

K. Barmak, W.J.M. de Jonge, T. Katayama, A. Schuhl, P. Dederichs

ISBN: 1-55899-379-7 Code: 475-B

$\begin{array}{lll}\$ 55.00 & \$ 65.00 & \text { MRS Member } \\ \$ 63.00 & \$ 75.00 & \text { U.S. List } \\ \$ 73.00 & \$ 86.00 & \text { Non-U.S. }\end{array}$

N: Low-Dielectric Constant Materials III Editors: C. Case, P. Kohl, T. Kikkawa, W.W. Lee ISBN: 1-55899-380-0 Code: 476-B
$\$ 48.00$
$\$ 57.00$
MRS Member
$\$ 55.00$
$\$ 66.00$
U.S. List
$\$ 63.00 \$ 76.00$
Non-U.S.

P: Science and Technology of Semiconductor Surface Preparation Editors: G.S. Higashi, M. Hirose, S. Raghavan, S. Verhaverbeke

ISBN: 1-55899-381-9 Code: 477-B

$\begin{array}{lll}\$ 50.00 & \$ 60.00 & \text { MRS Member } \\ \$ 58.00 & \$ 68.00 & \text { U.S. List } \\ \$ 66.00 & \$ 79.00 & \text { Non-U.S. }\end{array}$

Q: Thermoelectric Materials-New Directions and Approaches

Editors: T.M. Tritt, G. Mahan, H.B. Lyon, Jr., M.G. Kanatzidis

ISBN: 1-55899-382-7 Code: 478-B

$\begin{array}{lll}\$ 52.00 & \$ 62.00 & \text { MRS Member } \\ \$ 60.00 & \$ 71.00 & \text { U.S. List } \\ \$ 69.00 & \$ 82.00 & \text { Non-U.S. }\end{array}$

S: Materials for Optical Limiting II Editors: P. Hood, R. Pachter, K. Lewis, J.W. Perry, D. Hagan, R. Sutherland

ISBN: 1-55899-383-5 Code: 479-B

$\begin{array}{lll}\$ 52.00 & \$ 62.00 & \text { MRS Member } \\ \$ 60.00 & \$ 71.00 & \text { U.S. List } \\ \$ 69.00 & \$ 82.00 & \text { Non-U.S. }\end{array}$

Z: Specimen Preparation for Transmission Electron Microscopy of Materials IV

Editors: R.M. Anderson, S.D. Walck

ISBN: 1-55899-384-3 Code: 480-B

$\begin{array}{lll}\$ 45.00 & \$ 54.00 & \text { MRS Member } \\ \$ 52.00 & \$ 62.00 & \text { U.S. List } \\ \$ 60.00 & \$ 71.00 & \text { Non-U.S. }\end{array}$

These books are scheduled
for publication by fall or early
winter 1997.




\section{The art of materials technology... SPECIAL OFFER! JMR on CD-ROM}

Joumal of MATERIALS RESEARCH

Over a decade ago Materials Research Society had a vision - to produce an archival publication unlike any other. JMR is devoted to original research encompassing all aspects of materials science. JMR - more than ever -the archival front-runner in international materials research.

Designed for scientists, researchers, engineers, and students, this collection contains the entire contents of JMR Volume 11 • 1996.

\section{JMR CD-ROM}

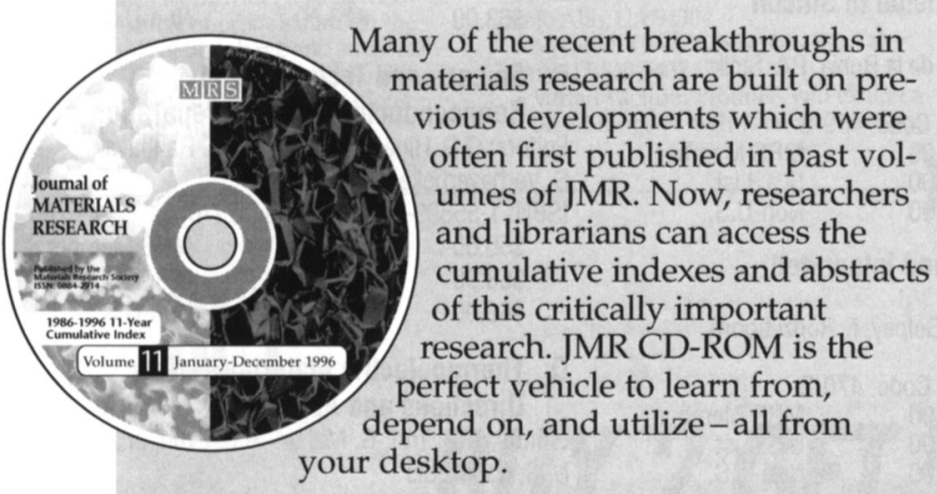

Also included on the CD-ROM are cumulative indexes to all the volumes of JMR published from 1986 through 1996. The cumulative indexes provide an easy, time-saving way to find virtually every topic ever published in JMR .

\section{Some Key Features}

This CD-ROM allows the user to:

- Utilize Adobe Acrobat Reader ${ }^{\mathrm{TM}}$

- Work with an easy-to-learn interface to Windows, Macintosh, or Unix computers

- Search by multiple methods, including title, author, subject, or key word in the text

- Move quickly and non-sequentially from one page to another
O U.S. Member . $\$ 75$

O Non-U.S. Member $\$ 88$

Optional Air Freight (non-U.S.) $\$ 76$

INCLUDED WITH YOUR 1997 SUBSCRIPTION:

JMR VOL. 12, 1997 on CD-ROM, to be shipped in 1st quarter 1998.

\section{EXTRA BONUS}

JMR VOL. 11, 1996 on CD-ROM, to be shipped in 1st quarter 1997. Includes JMR Cumulative Index

\author{
Journal of Materials Research on CD-ROM Order Form \\ O Payment enclosed (Check or money order in US Dollars) \\ OMaster Card O VISA O American Express ODiner's Club \\ Card Number \\ Expiration Date (Month/Year) \\ Card Holder's Signature \\ Name \\ Institution \\ First \\ Middle \\ Last

Institute Government O Laboratory O Industry O Other \\ Dept/Mail Stop \\ P.O. Box _ Street \\ Postal Code 1 \\ City \\ Postal Code 2

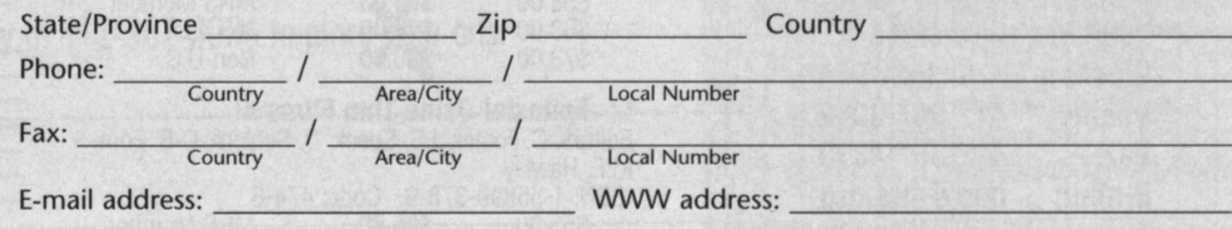

